\title{
DON ANTE ADŽIJA - ZABORAVLJENI STARIGRADSKOPAKLENIČKI VELIKAN
}

Mirjana Trošelj

Donje Vrapče 58

HR10000 Zagreb

mitroselj@gmail.com
UDK: 272(497.5 Starigrad)

Izvorni znanstveni članak

Ur.: 2017-01-28

U radu se prikazuje izuzetan životopis župnika don Ante Adžije (1880.- 1944.), najznačajnije i najistaknutije osobe 20. st. u Starigradu-Paklenici, koji je nepravedno i neopravdano zapostavljen u sagledavanju pastoralnog, humanitarnog, kulturološkog, socijalno-ekonomskog, prosvjetiteljskog i drugih djelovanja u župi u razdoblju između dva svjetska rata. Njegovom zaslugom selo iz prve polovice 20. st. postalo je najrazvijenija turistička općina na potezu od Karlobaga do Zadra. Svrha ovoga rada je senzibilizirati svijest o takvim pojedincima, velikanima, koji su svojim radom zadužili svoj narod i kulturu kojoj pripadaju.

Rad se sastoji od tri dijela. U prvom se govori o životnom putu, podrijetlu, školovanju i svećeničkoj djelatnosti do premještanja u župu Starigrad-Paklenica 1923. U drugom dijelu govori se o radu u novoj župi na vjerskom, kulturno- povijesnom, prosvjetiteljskom, zdravstvenom, planinarsko-turističkom i gospodarskom planu kako bi joj u "najpustijem kraju Zadarske nadbiskupije"1 postavio temelje za svekoliki napredak. Na tim zasadama StarigradPaklenica razvio se u modernu turističku općinu. U povijesnom kontekstu Prve Jugoslavije u otežalim društveno-političkim i ekonomskim prilikama, koje su se odrazile i u pasivnim krajevima Podgorja, don Ante Adžija nije gubio vjeru u ostvarenje svojih mesijanskih ciljeva. Volio je svoj narod, svoje Starogradce i kao Božji poslanik koristio sve prilike i mogućnosti da im pridonese boljitak. Radi toga je razvijao suradnju s uglednim ličnostima iz društveno-političkog, gospodarskog i kulturnog kruga Primorske i Savske banovine (od Rijeke do Splita i Zagreba), uglednih znanstvenika, znanstvenika-planinara iz Hrvatske i inozemstva. Poseban osvrt u radu je na njegovu istraživanju kulturno-povijesne baštine, prikupljanju arheološke građe (antičke i starohrvatskih sakralnih spomenika), utemeljenju muzeja u župnoj kući, obnovi i uređenju sačuvanih sakralnih objekata. Kao suradnik Muzeja hrvatskih spomenika i član Starinarskog muzejskog društva u Kninu, sudjelovao je 1941. u spašavanju starohrvatske baštine s područja sjeverne Dalmacije. U trećem dijelu umjesto zaključka, govori se da ga ni okolnosti Drugog svjetskog rata nisu omele, premda je slutio smrt već 1941., da nesebično radi za svoju župu i župljane i da kao Spasitelj spašava čovjeka, svoj narod i njegovu baštinu, sve do svoje mučeničke smrti 1944. 
Ovaj rad baziran je na zapisnicima Podružnice HPD "Paklenica,"pod nazivom Starigrad pod Velebitom iz Arhiva muzeja Samobor, člancima iz časopisa "Hrvatski planinar" iz Arhiva HPS-a Zagreb (od 1923. do 1940.), novinskim člancima i obiteljskom foto-materijalu i materijalu iz nepoznatih izvora na stranicama Facebooka. U radu su uključena i svjedočanstva uže rodbine don Ante Adžije, mještana na starigradskoj Punti, zapisa uglednih planinara i drugih koji su ga poznavali. Budući da se stručna literatura nije do sada ozbiljno bavila njime, osim kratkih zapisa o pastoralnom radu prije dolaska u župu Starigrad-Paklenica i nekoliko podataka, uglavnom nepotpunih i netočnih, o njegovoj smrti. Starigradskopakleničko stvaralačko razdoblje od 1923. do 1944., do danas nije ušlo u stručnu literaturu, osim skromnog zapisa autorice povodom 60 . obljetnice njegove smrti. ${ }^{2}$ Zato ovaj rad valja promatrati kao polazište za buduća istraživanja, temeljena na eventualnoj nepoznatoj arhivskoj građi koja u danom trenutku nije bila dostupna. To se u prvom redu odnosi na arhivsku dokumentaciju banske uprave obiju Banovina i državne uprave.

Sva njegova rukopisna građa i dokumentacija čuvana u župnoj kući i župnoj crkvi sv. Jure spaljena je 1944., a jedan dio pisane sakralne građe bačen je u more, čime je oštećen njegov pastoralni i istraživačko-stvaralački životopis, a time i "životopis" starigradskopakleničke povijesti.

Ključne riječi: don Ante Adžija, Starigrad - Paklenica

\section{I. Životopis}

Don Ante Adžija rođen je 7. svibnja 1880. u Sinju. Pučku školu i Franjevačku klasičnu gimnaziju završio je u rodnom gradu. Na Visovcu je zaređen 6. rujna 1897. uzevši ime Zvonimir, a 1898., dobio je novo ime fra Bartul. S Visovca odlazi u Šibenik radi studija filozofije i teologije. Nakon završenog studija zaređen je za svećenika 30. rujna 1902. Uprava Provincije šalje ga u samostan u Karinu. Od 1909. župnik je u Zlopolju, a od 16. travnja 1912. upravitelj župe Kruševo u novigradskom dekanatu. U svojoj 44. godini prelazi iz redovničke zajednice franjevaca Provincije presv. Otkupljenja u redove biskupijskih svećenika Zadarske nadbiskupije. ${ }^{3}$ Potonji biografski podatak nije posve jasan pa nismo sigurni do kada je bio u župi Kruševo i koje je godine prešao u biskupijske svećenike? Ako se prijelaz, kako se navodi, zbio u 44. godini života,

${ }^{1}$ Župa je pripadala Novigradskom dekanatu kao Apostolska administratura Jugoslavenskog dijela Zadarske nadbiskupije sa sjedištem u Šibeniku. Informacija: don Oleg PETROVIĆ, mag. hist., Arhiv biskupije Šibenik, 2017.

${ }^{2}$ M. TROŠELJ, 2003, 121-123.

${ }^{3}$ Vidi: R. ŠUTRIN, 1995, 2002; R. JURIĆ, 2003, 2013; A. BAKOVIĆ, 2007; P. KERO, 2009. prema R. ŠUTRINU. Svi noviji, kao i oni stariji pisani izvori donose samo nepouzdane podatke o njegovoj smrti. Ovdje je uvršten i citiran R. Šutrin poradi vrlo sažetih biografskih podataka don Ante Adžije do dolaska u župu Starigrad-Paklenica. 


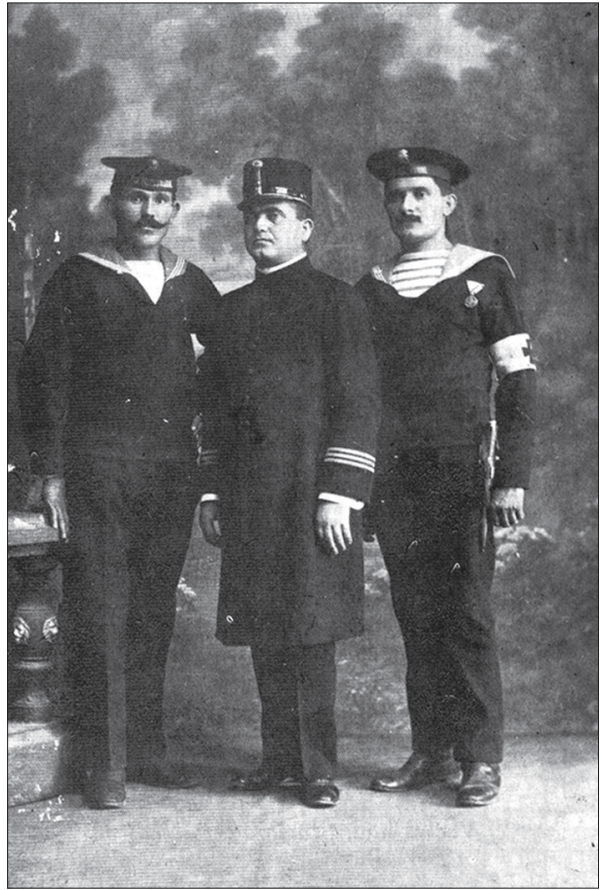

Sl. 1. Don Ante Adžija, vojni kapelan u austrougarskoj vojsci, godina i snimatelj nepoznati (privatni arhiv pok. dr. Darinke Čop)

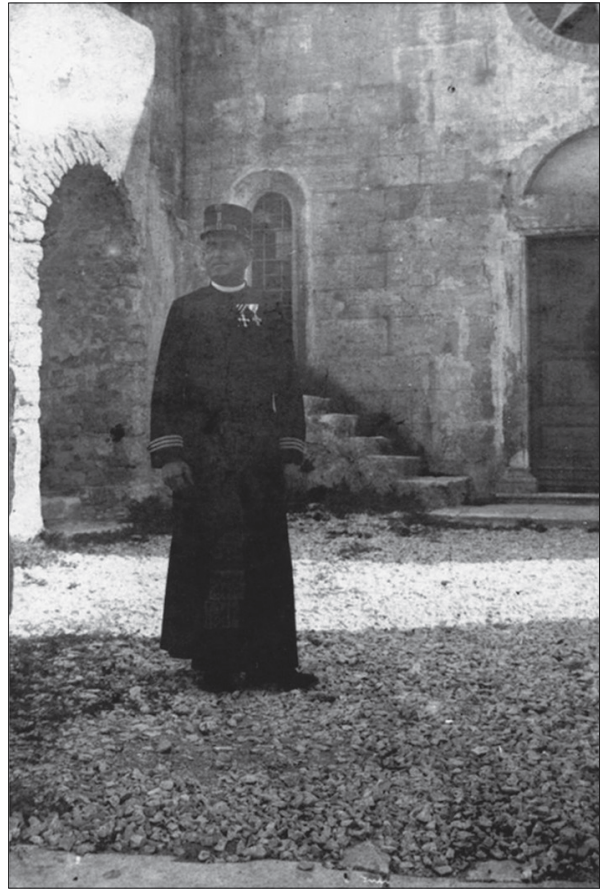

Sl. 1a. Don Ante Adžija, vojni ordinarij u Puli u Prvom svjetskom ratu, godina i snimatelj nepoznati (privatni arhiv pok. dr. Darinke Čop)

onda je to moglo biti 1923., neposredno prije dragovoljnog premještanja u novu župu Starigrad-Paklenicu. Stari Puntari sjećali su se u svojim kazivanjima 1985., da je došao u selo kaj pop, a ne vratar. ${ }^{4}$ Ovu biografsku nejasnoću svakako će u buduće trebati rasvijetliti, premda je 2008. moju pretpostavku potvrdila njegova nećakinja dr. Darinka Čop (1924.-2013.) i nadopunila njegovu biografiju podatkom da je bio vojni kapelan u vojsci Austro-Ugarske monarhije u Puli, a u Prvom svjetskom ratu vojni ordinarij također u Puli (sl. 1, sl. 1a). Taj se podatak ne navodi u literaturi. Istakla je da Adžije nisu podrijetlom iz Sinja, nego iz Karlobaga. Djed i njegova braća odselili su iz Karlobaga u Sinj oko sredine 19. st. po nekoj obvezi (službenoj ili privatnoj, nije se sjećala). Od 1923. župnik je u Starigradu-Paklenici do svoje tragične smrti 1944. Selo je od iste godine 1923.1940. u sastavu općine Novigrad i Novigradskog dekanata (Vidi bilješku 1).

\footnotetext{
${ }^{4}$ Kazivanja: Ivica Trošelj (1921-2012.) i Grga Smokrović (1925-2000.).
} 


\section{Pastoralni rad u novoj župi}

Za ambiciozne i uspješne svekolike djelatnosti don Ante Adžije u novoj župi, prethodila su povijesna zbivanja u okruženju južnog Velebita i Podgorja, koja su mu kasnije bila poticaj za aktivno sudjelovanje u tim zbivanjima, i to u stvaralačkom, a ne političkom kontekstu. To se u prvom redu odnosi na planinarska znanstvena istraživanja Velebita koja su započela u 19. i nastavila se u 20 st. Isprva su to vršili stranci s područja Austro-Ugarske monarhije, a ubrzo se uključuju i hrvatski znanstvenici nekad bečki studenti, kao što su Dragutin Franić, Dragutin Hirc, Radivoje Simonović, Josip Pasarić, Vjekoslav Cvetišić, Ivo Juričić, Miroslav Hirc, Ivan Krajač, Ivo Gojtan, Branimir Gušić, Josip Poljak, Ivo Horvat i drugi. ${ }^{5}$ Do dolaska don Ante Adžije navedena planinarskoistraživačka skupina otkrivala je prirodne znamenitosti južnog Velebita, osobito Paklenice i kulturno-antropološka obilježja planinskog stočarskog stanovništva. ${ }^{6}$ U Starigradu-Paklenici tada već postoje nužni objekti za prihvat i smještaj planinara-istraživača, turista i drugih gostiju, kao što su gostionica braće Veršić Moka (iz 19. st.), gostionica "Bušljeta i sin" i povremeno upravna zgrada Šumarije. U to vrijeme službovao je u Starigradu-Paklenici učitelj Mihovil Maričić, podrijetlom iz Obrovca, budući prijatelj i suradnik don Adžije u razvoju malog i siromašnog sela. Zbog nedostatka prometnica prilaz južnom Velebitu uglavnom se odvijao s ličke strane od Metka preko Paklenice do Starigrada ili od Počitelja preko Oglavinovca do Rujna i Sarigrada-Paklenice. Parobrodska linija Sušak - Obrovac pristajala je u Vinjercu pa su se planinari i turisti iz Vinjerca prevozili privatnim gajetama u Starigrad-Paklenicu. ${ }^{7} \mathrm{U}$ takvim povijesnim okolnostima došao je don Ante Adžija u svoju novu župu.

Prikaz prvih godina pastoralnog rada (od dolaska 1923. do 1930.), bazira se na sjećanjima kazivača Puntara, planinarskim člancima i službenim vijestima HPS-a, budući da u danom trenutku o Kanonskim vizitacijama nismo imali dostupne podatake. Već na samom početku u pustom i siromašnom kraju posvećuje se upoznavanju svoje nove župe i župljana koji su se bavili transhumantnim stočarenjem: zimi u Podgorju ili zaselcima na prvim podima, ljeti u planini u ljetnim stanovima s blagom na ispaši. Obilazio je naselja župe radi upoznavanja socijalno-ekonomskih prilika župljana u planini. Budući da u selu nije bilo liječnika, često je pozivan u planinska naselja prvih poda i stočarske

${ }^{5}$ Ž. POLJAK i suradnici, 1969, 117-130.

${ }^{6}$ Ž. POLJAK i suradnici, 1969, 117-130.

${ }^{7}$ I. JURIČIĆ, 1912, 61. 
stanove (Veliko Rujno, Mali Javornik) da bolesnom članu obitelji molitvom i blagoslovom ulije vjeru i nadu u ozdravljenje. Isto je činio i za bolesno blago i druge vrste nedaća koje su im ugrožavale egzistencijalni opstanak. Pozivan je i za blagoslov blaga prije prtljanja u planinu na ljetnu ispašu, da bi blago bilo zdravo, a ispaša dobra. ${ }^{8}$

Već na početku svoga pastoralnog djelovanja upoznaje se s utjecajnim ljudima u selu: bivšim glavarom Jandrom Čavićem i novim Antom Bušljetom, trgovcem Stipanom Bušljetom, učiteljem Mihovilom Maričićem i njegovom suprugom Marijom, Markom Veršićem Mokom, jednim od braće vlasnika gostionice Moka, podrijetlom iz Vinjerca i drugim žiteljima. U njima je prepoznao mogućnost bliske suradnje i potpore u prosperitetu sela. ${ }^{9} \mathrm{U}$ prvim pastoralnim vizitacijama puntarskih naselja i raštrkanih zaselaka po Velebitu upoznao se sa svekolikim životom župljana, osobito na ljetnoj ispaši na Velikom Rujnu. Prvih godina nakon dolaska u novu župu, zamijetio je na blagdan Velike Gospe na Velikom Rujnu veliki broj hodočasnika; uz domaće žitelje i hodočasnike iz susjednih krajeva (Ravni kotari, Bukovica, Lika), planinareturiste iz svih krajeva Primorske i Savske banovine i bližih europskih zemalja (Austrije i Čehoslovačke). Spoznao je da selo ima veliki planinarsko-turistički potencijal, jer su ga još prije njegovog dolaska posjećivali poznati planinarivelebitaši, znanstvenici, tijekom istraživanja prirodnih i kulturnih znamenitosti južnog Velebita, ali i drugi domaći i strani posjetitelji. Uvidio je da je stara i trošna suhozidna crkvica Podgradinom premalena za župljane i goste pa je župljanima iznio ideju o gradnji nove crkve. Ta se ideja realizirala 1930. i crkva je bila izgrađena za osam dana, uz financijsku pomoć Primorske banovine, Podgoraca i podgorskih iseljenika u Americi i Slavoniji. Na pročelju stoji natpis da ju je podigao "Pomoću Boga i Starigradaca na čast Velike Gospe don Ante Adžija godine 1930." Kraj crkve je 1932. dao dozidati gusternu/čatrnju s natpisom "Za banovanja dr. Tartagliae, dr. Jablanovića, načelnika tehničkog odjela i ing. Matulovića." Sakrstija uz crkvu s posebnim ulazom na zapadnoj strani služila je planinarima za sklonište od nevremena i eventualno prenoćište do izgradnje novog planinarskog skloništa 1937. Na dan Velike Gospe 1930. (Sl. 2), održana je svečana misa i posvećenje crkve. Za tu prigodu pozvan

${ }^{8}$ Kazivanja M. Čavića i B. M. Bušljete-Tumbana, prema kazivanjima svojih djedova, koji su bili svjedoci pastoralonog rada don Ante Adžije. Kazivači nisu dopustili da im se iznosi puni identitet kao i identitet njihovih djedova. Kazivanja su iznosili gđi Miri Višić u StarigraduPaklenici, r. 1957., u dva navrta: 2012. i 2016.

${ }^{9}$ Isti i I. Trošelj (1921-2012.). 


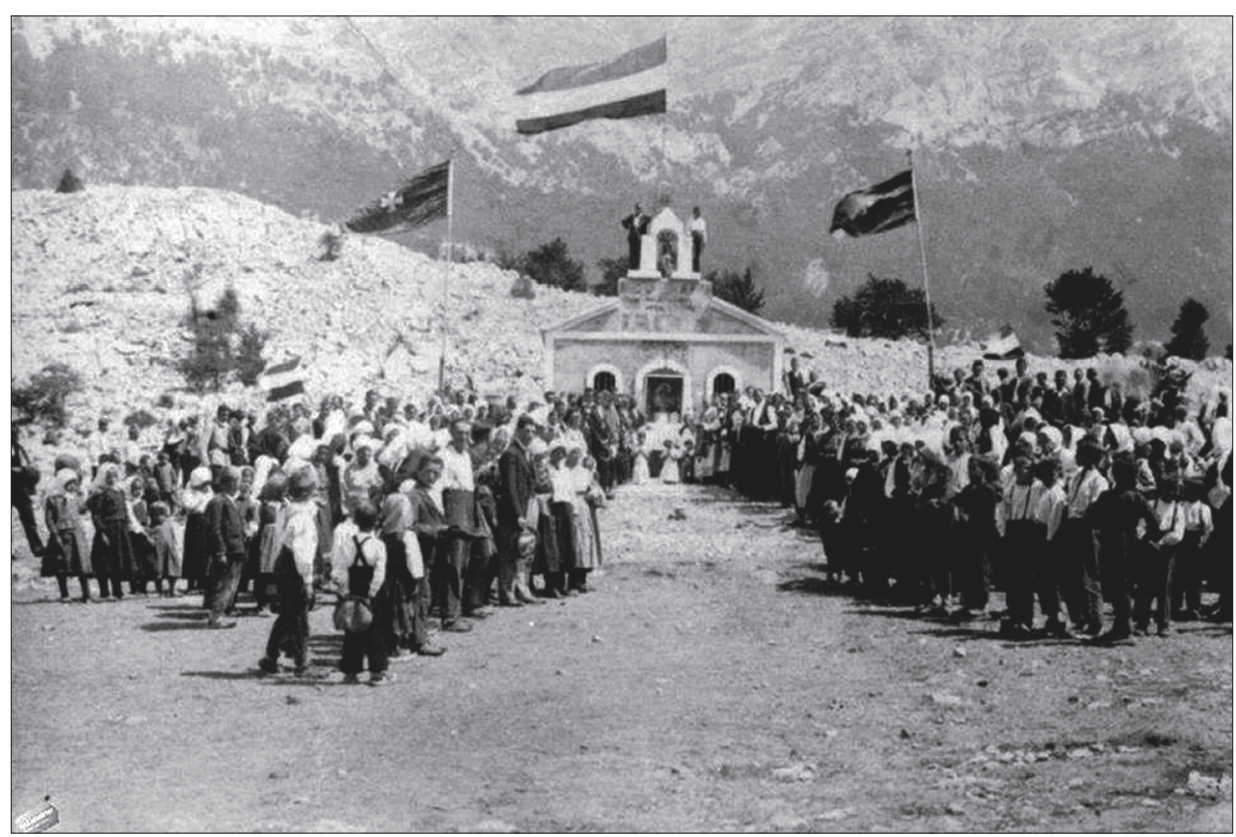

S1. 2. Nova crkva Velike Gospe na V. Rujnu izgrađena 1930. na inicijativu don Ante Adžije, snimatelj nepoznat, izvor: https://hr-hr.facebook.com/Stare slike i razglednice Starigrada-Paklenice i okolice

je planinar, ministar gospodarstva i trgovine Ivan Krajač da bude kum pri svečanom blagoslovu crkve. Darovao je novčani prilog za gradnju planinarskog skloništa i već spomenute gusterne uz crkvu. Tim čestitkama i daru pridružio se Upravni odbor Središnjice HPD i drugi ugledni gosti. ${ }^{10}$ Ovaj pothvat don Adžije imao je odjeka u Hrvatskoj i bliži nam europskim zemljama. ${ }^{11}$ Česti gosti bili su župnici iz drugih župa koji su na njegov poziv dolazili u hodočašće Majci Božjoj na južni Velebit (Sl. 3). U prilog tome govore medijski zapisi, pisma i čestitke upućene iz Uprave obiju Banovina, od prijatelja i znanaca iz Hrvatske, grada Beča i Praga s kojima je imao bliske rodbinske i prijateljske veze. ${ }^{12} \mathrm{U}$

${ }^{10}$ Vidi članak anonimnog autora iz Arhiva župe Starigrad-Paklenica u: A. RUKAVINA, 1989, 85-87;

${ }^{11}$ Brzojavna čestitka dr. Roberta Stiglera iz Beča, vidi zapis anonimnog autora u nepoznatim novinama u: A. RUKAVINA, 1989.,86 i čestitka Mare Adžije iz Praga, Čehoslovačke državljanke, prema kazivanju dr. Darinke Čop.

${ }_{12}$ Časopis "Hrvatski planinar "-Društvene vijesti, br. 9, Zagreb, 1930, 301-302.; Informacije nećakinje don Ante Adžije pok. dr. Darinke Čop, 2008, prema kazivanju Mare Adžije iz Praga, sestre don Ante Adžije i prof. dr. Roberta Stiglera iz Beča, pobratima don Ante Adžije. 


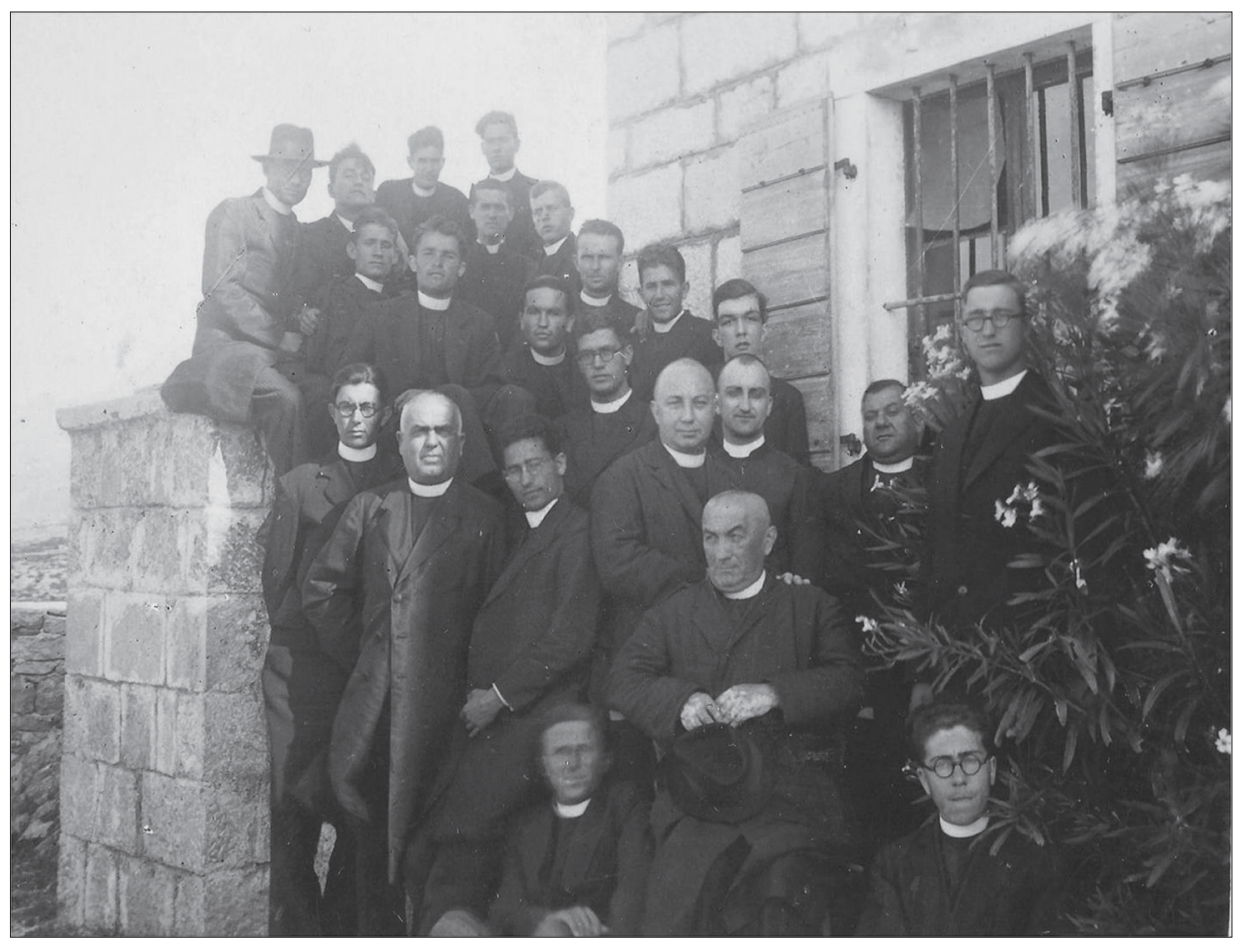

Sl. 3. Gostujući župnici don Ante Adžije ispred Popove kuće, godina i snimatelj nepoznati, izvor: https://hr-hr.facebook.com/Stare slike i razglednice Starigrada-Paklenice i okolice

glasilu Središnjice HPD-a "Hrvatski planinar" posvetio mu je planinar i prijatelj Umberto Girometta pohvalan članak o izgradnji crkve. ${ }^{13}$

\section{Planinarsko-turistički rad: Utemeljenje HPD Podružnice "Paklenica"}

Za sve nove zamišljene projekte koji bi selo i njegove žitelje podizali i razvijali na gospodarskom, prosvjetiteljskom, kulturnom i zdravstvenom planu, don Ante Adžija je došao do zaključka da se oni mogu realizirati samo utemeljenjem neke udruge koja bi stajala iza pokrenutih projekata, jer selo nema nikakve društveno-političke institucije koja bi ih pokretala i ostvarivala (Sl. 4). Tako je 21. 8. 1932., prigodom boravka u selu prijatelja planinara Umberta Giromette iz Splita, pokrenuo prijedlog osnutka planinarskog

${ }^{13}$ U. GIROMETTA, 1933, 106-113. 


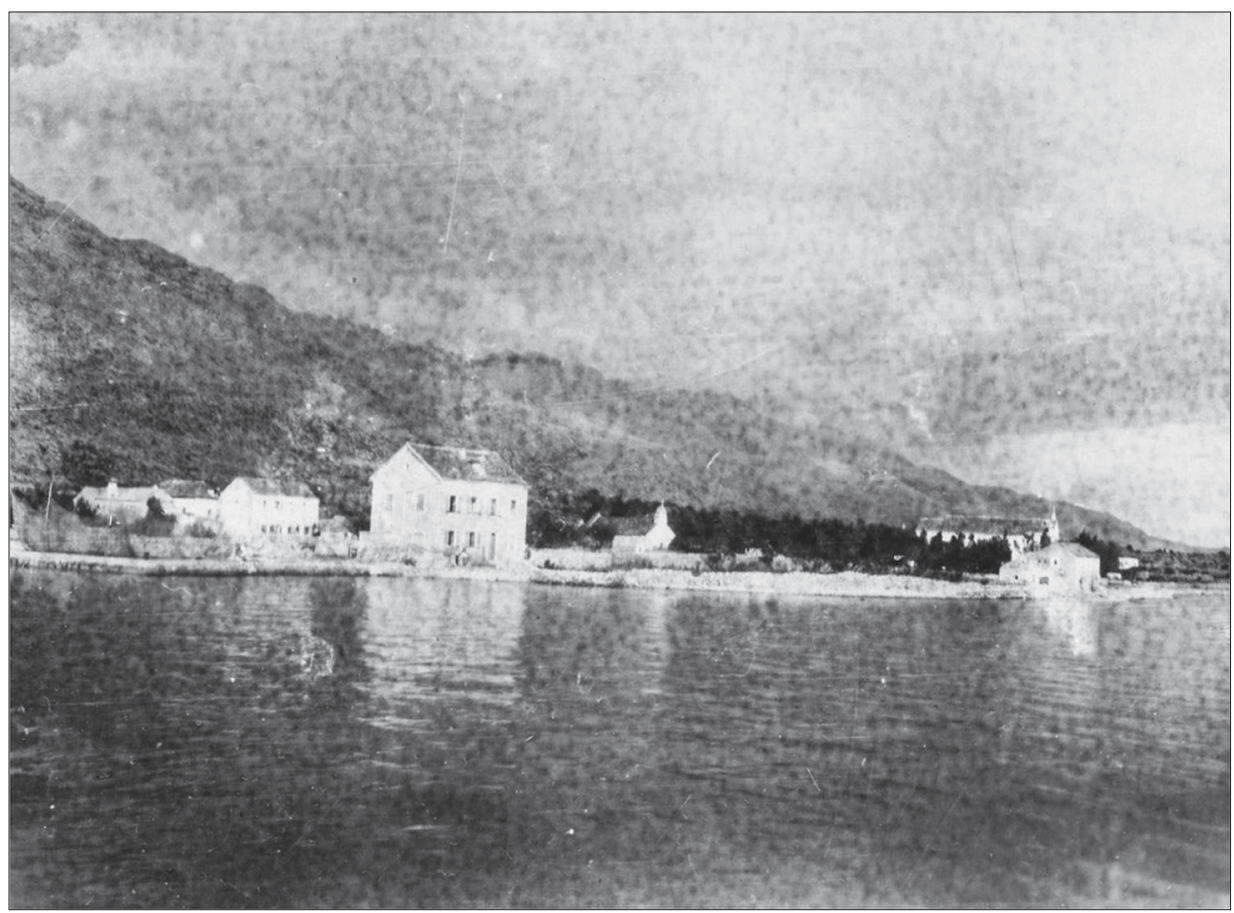

S1. 4. Starigrad-Paklenica, naselje Punta u doba don Ante Adžije, godina i snimatelj nepoznati, izvor: https://hr-hr.facebook.com/Stare slike i razglednice StarigradaPaklenice i okolice

društva. ${ }^{14}$ Sastavljen je uži odbor za osnutak podružnice HPD "Paklenica" sa sjedištem u "Starigradu pod Velebitom". Podružnica je 23. 4. 1933. potvrđena u Središnjici, zahvaljujući Umbertu Girometti i Ivanu Krajaču. Predsjednik je bio don Ante Adžija, a tajnik učitelj Mihovil Maričić. Broj članova kretao se od deset do petnaest, već prema njihovim novčanim mogućnostima, poradi plaćanja članarine Središnjici. ${ }^{15}$ Sastanci su se održavali redovito i slala se izvješća Središnjici HPD-a u Zagrebu. ${ }^{16}$

Cilj Podružnice očitovao se u smjeru poboljšanja i razvoja gospodarskih prilika na području Starigrada-Paklenice, osobito gradnji prometnica i planinarskih putova za razvoj turizma i prosvjećivanja na svim razinama,

${ }^{14}$ Zapisnik od 21. 8. 1932., Arhiv muzeja Samobor.

${ }^{15}$ Vidi zapisnik od 23. 4. 1933, Arhiv muzeja Samobor: S28, Starigrad pod Velebitom.

${ }^{16}$ Vidi zapisnike i dopise između HPD Podružnice "Paklenica" i HPD Središnjice u Zagrebu od 21. 8. 1932. do ukidanja Podružnice 1. 1. 1940, Arhiv muzeja Samobor. 
zaštiti prirodnih (osobito pakleničkih šuma) i kulturnih resursa, a ne osobnog planinarenja, jer zato nije bilo vremena ni potrebe, jer su članovi svakodnevno išli po planini radi stočarskih i poljodjelskih poslova. Promicali su planinarstvo u Paklenici, svjesni da će ono pridonijeti poboljšanju društveno-ekonomskih prilika sela. Zajedno s obitelji Maričić i članovima Podružnice HPD-a, g. 1930. don Adžija apelira vlasti da zaštiti šume Paklenice od sječe koju su vršili Talijani iz Zadra i Italije. Već iste godine zauzeo se Ante Premužić i Andrija Perušić da se spriječi sječa pa je Direkcija šuma na Sušaku preuzela Paklenicu u svoje nadleštvo. ${ }^{17} \mathrm{~S}$ nakanom da privuče što više planinara $\mathrm{i}$ turista na područje V. Rujna i Paklenice, i iz Hrvatske i inozemstva, osobito na blagdan Velike Gospe, don Adžija je surađivao s drugim HPD Podružnicama, kao što su HPD "Visočica" Gospić, HPD "Mosor" Split, HPD "Velebit" Rijeka. Radi toga je planirao izgradnju "Planinarskog morskog doma" na Večkom polju da bi planinari imali i morski turistički smještaj. O toj ideji planirao je razgovarati s Antom Premužićem. Nažalost, taj projekt nije stigao realizirati, zbog započetih ratnih previranja. Stalnu suradnju razvijao je sa Središnjicom u Zagrebu ne samo pismenim putem, nego i osobnim kontaktima, kako bi što uspješnije realizirao ideje i planove u izgradnji Starigrada-Paklenice. Bio je pretplaćen na časopise "Hrvatski planinar" i "Hrvatska straža" preko kojih je također pratio planirane aktivnosti Središnjice na Velebitu. ${ }^{18} \mathrm{U}$ zapisniku od 20. 5. 1934., izjavio je da je društvo u prvom redu osnovano da pridigne moralno i materijalno ove prirodne krajeve, od čega će imati korist stanovnici sela. ${ }^{19}$ 1. 1940.

Zbog ratnih i financijskih okolnosti podružnica je prestala djelovati od 1 .

\section{Rad na razvoju gospodarstva}

\section{Prometnice}

Don Ante Adžija, obdaren providnošću znao je da bez prometnica nema razvoja gospodarstva u selu. Tako je prvi prometni projekt bila izgradnja puta Obrovac - Tribanj-Mandalina (1930.), uz potporu Primorske banovine, bana I. Tartaglie i načelnika Tehničkog odjela ing. Matulovića. Put je proglašen banovinskim putom II. reda (Sl. 5). Ivan Krajač izvještava o tom uređenom Samobor.

${ }^{17}$ U pismu Središnjici 24. 4. 1933., Starigrad pod Velebitom, pošta Obrovac, Arhiv muzeja

${ }^{18}$ Iz zapisnika od 7. 8. 1933, Arhiv muzeja Samobor.

${ }^{19}$ Iz zapisnika od 18. 2. 1940, Arhiv muzeja Samobor. 


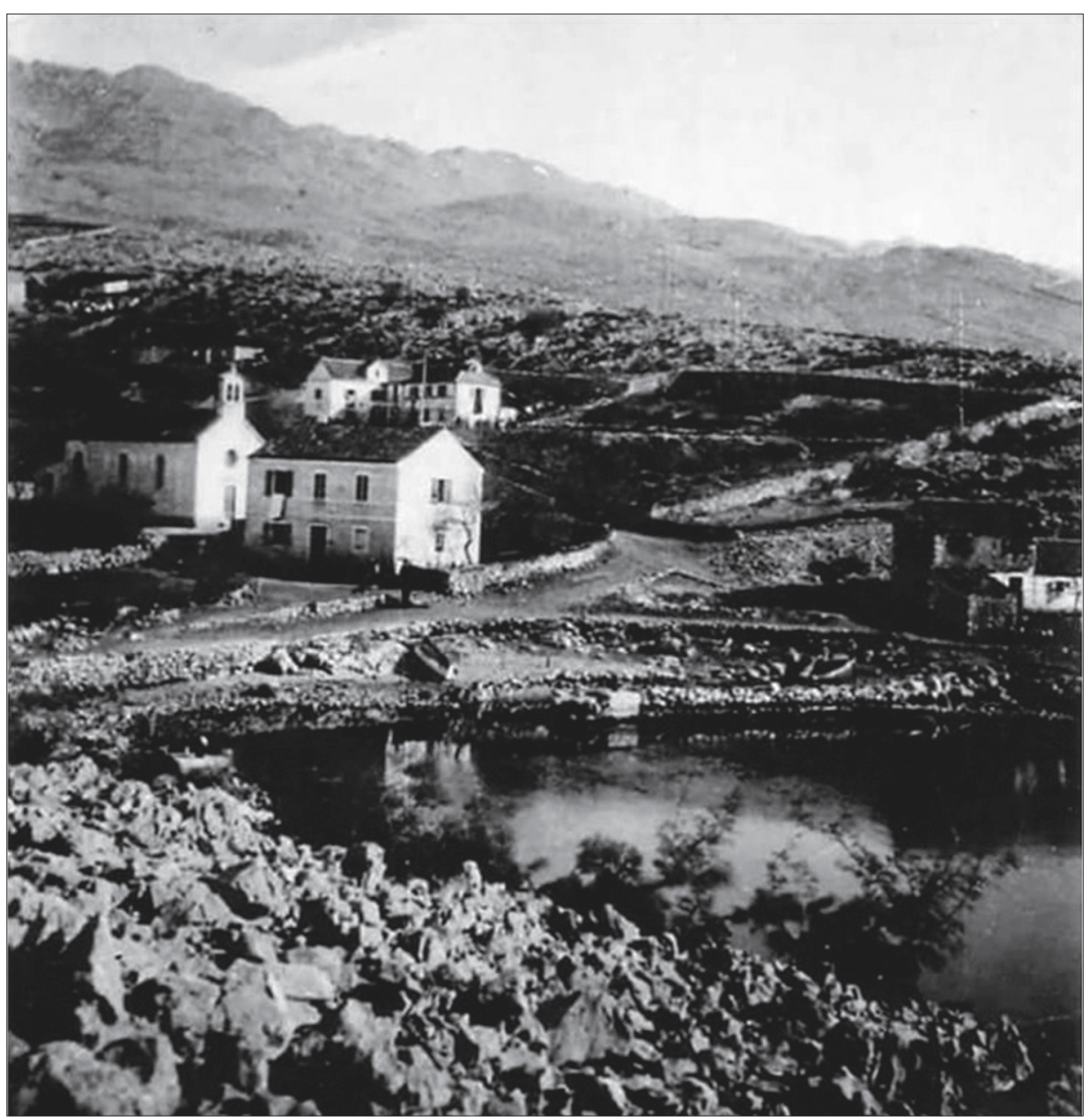

S1. 5. Uređeni pješački put od Obrovca do Tribnja-Mandaline, 1930., na slici TribanjKruščica, snimatelj nepoznat, izvor: https://hr-hr.facebook.com/Stare slike i razglednice Starigrada-Paklenice i okolice

obalnom put od Maslenice do Tribnja-Mandaline i uz njega postavljene telegrafske stupove. ${ }^{20}$ Iste se godine dogovorio s direktorom Direkcije šuma Sušak, Andrijom Perušićem, o izgradnji ceste od Obrovca do TribnjaMandaline, granice Savske i Primorske banovine, da bi se prometno povezalo

${ }^{20}$ I. KRAJAČ, 1930, 311-316. 


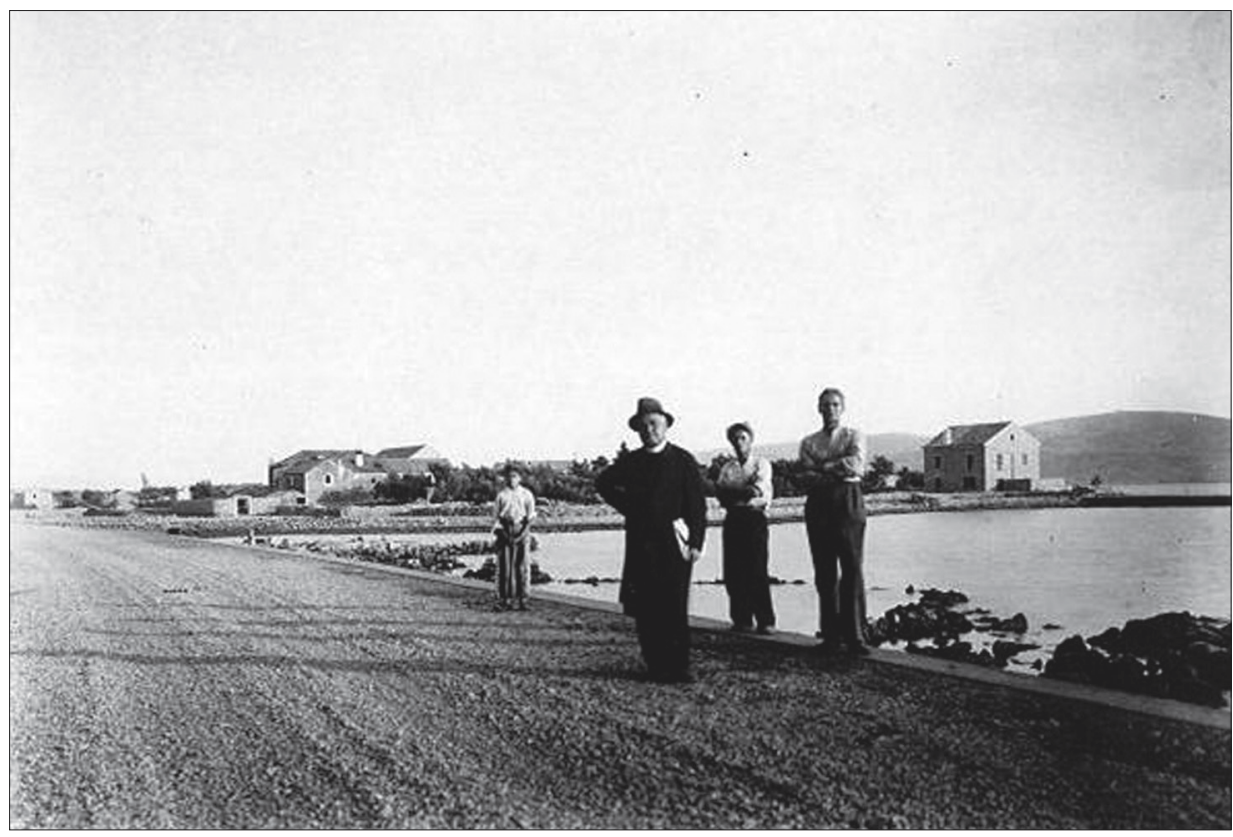

S1. 6. Završena Bila cesta don Ante Adžije od Obrovca do Tribnja-Mandaline na granici Savske i Primorske banovine 1937. Na slici centar Starigrada-Paklenice (Arhiv muzeja Samobor, snimatelj R. Simonović, 1937., foto: fond R. Simonovića)

Sušak i Dalmaciju. Probijanjem ceste oživjet će više naselja i omogućiti im lakši i brži dolazak na trgovačke sajmene dane u Obrovcu i trgovanje u Ravnim kotarima. Promet turista bit će veći, što će umnogome doprinijeti poboljšanju ekonomskih prilika župe. Ban je odobrio sredstva za cestu i za gusternu na V. Rujnu pa im je gradnja započela iste 1930. godine, "a za čatrnju nadodao sam i sam nešto od mojega siromaštva."21 Podružnica je uspješno i ustrajno radila već od 1932. da započne probijanje Bile turističke ceste Obrovac - TribanjMandalina. Don Ante Adžija je s ponosom izjavio da je ta velika ideja rođena u našoj maloj Podružnici. Za dovršetak gradnje trebala su dodatna sredstva pa se obratio ministru Marku Kožulu koji je osobno došao i doznačio velika sredstva da se cesta dovrši, jer znači veoma važan turistički spoj Sušak Dalmacija. ${ }^{22}$ Treći prometni pothvat don Ante Adžije odnosio se na uređenje starih planinskih putova i gradnja novih. Prioritet za uređenje imao je paklenički

${ }^{21}$ Iz zapisnika od 24. 4. 1933, Arhiv muzeja Samobor.

${ }^{22}$ Iz zapisnika od 15. 4. 1935, Arhiv muzeja Samobor. 


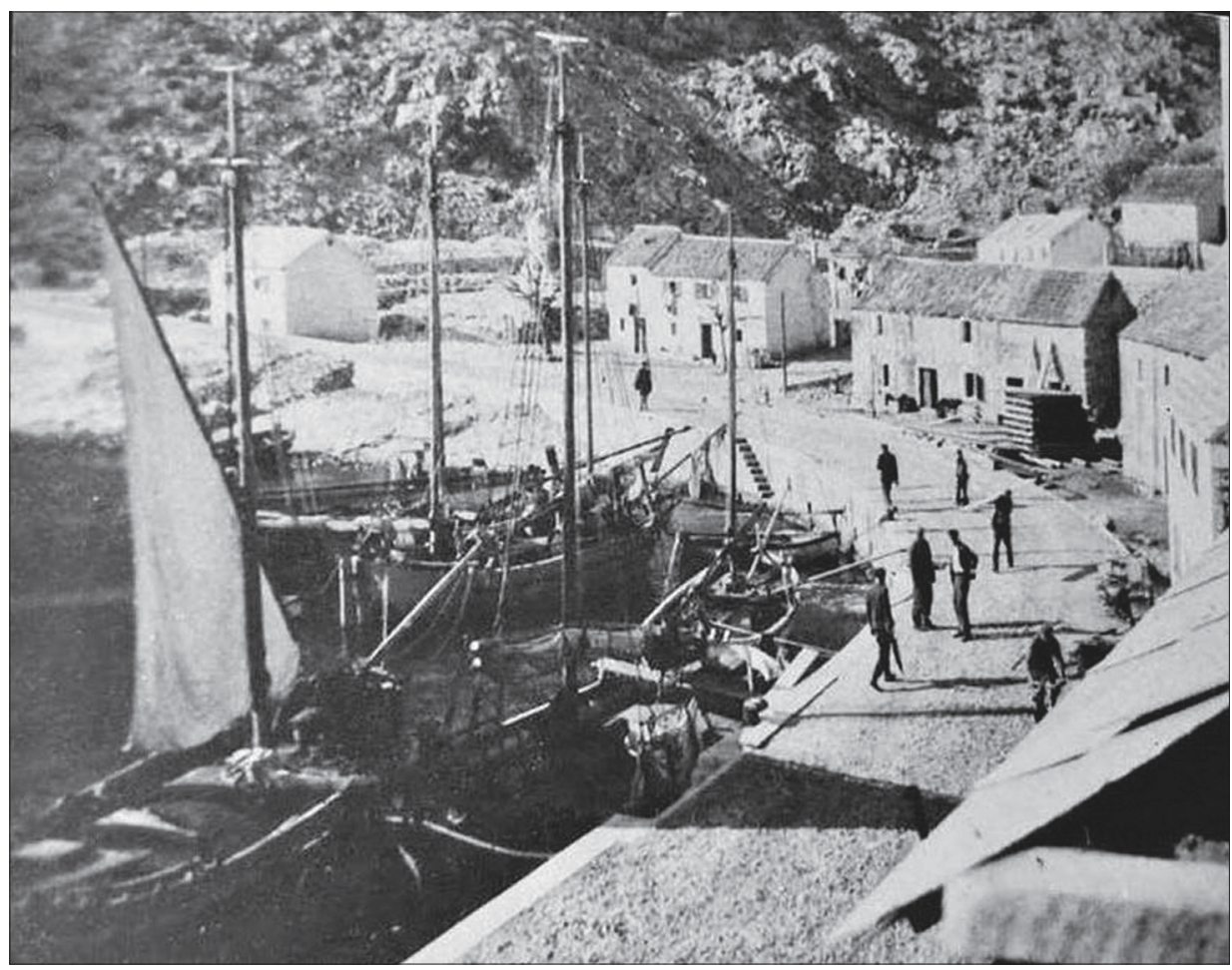

Sl. 7. Završena Bila cesta u Tribnju-Mandalini spojena s karlobaškom na Punti Mandalinskoj, 1937./1938., snimatelj R. Simonović, izvor: https://hr-hr.facebook.com/ Stare slike i razglednice Starigrada-Paklenice i okolice

put kroz Klance do Anić luke. Kako se posebno zanimao za špilju Manitu peć, kao izuzetnu prirodnu tvorevinu i buduću planinarsko-turističku atrakciju, zauzeo se kod Direkcije na Sušaku da se izgradi staza od Anić luke do Manite peći. Uređenje staze trajalo je od 1933. do 1935., a unutarnja staza u špilji i paklenički put od sela do Anić luke dovršeni su 1938. ${ }^{23}$ Za uspješno probijanje ceste prema Karlobagu 1937., don Ante Adžija organizirao je božićni ručak kod trgovca Stipana Bušljete, mješovita trgovina i gostionica "Stipan Bušljeta i sin" (S1. 5, 6, 7, 8). Brodski promet 1935. odvijao se dva puta tjedno Sušak - Obrovac i jednom tjedno Šibenik - Obrovac. Parobrodi koji su prometovali od Sušaka do Obrovca bili su Lloydov "Hebe" i "Gradac." Od 1937. prometuje parobrod "Pelješac" Sušak - Obrovac. ${ }^{24}$ Brigu oko čuvanja Manite peći i drugih

${ }^{23}$ Iz zapisnika od 3. 12. 1935, Arhiv muzeja Samobor. 


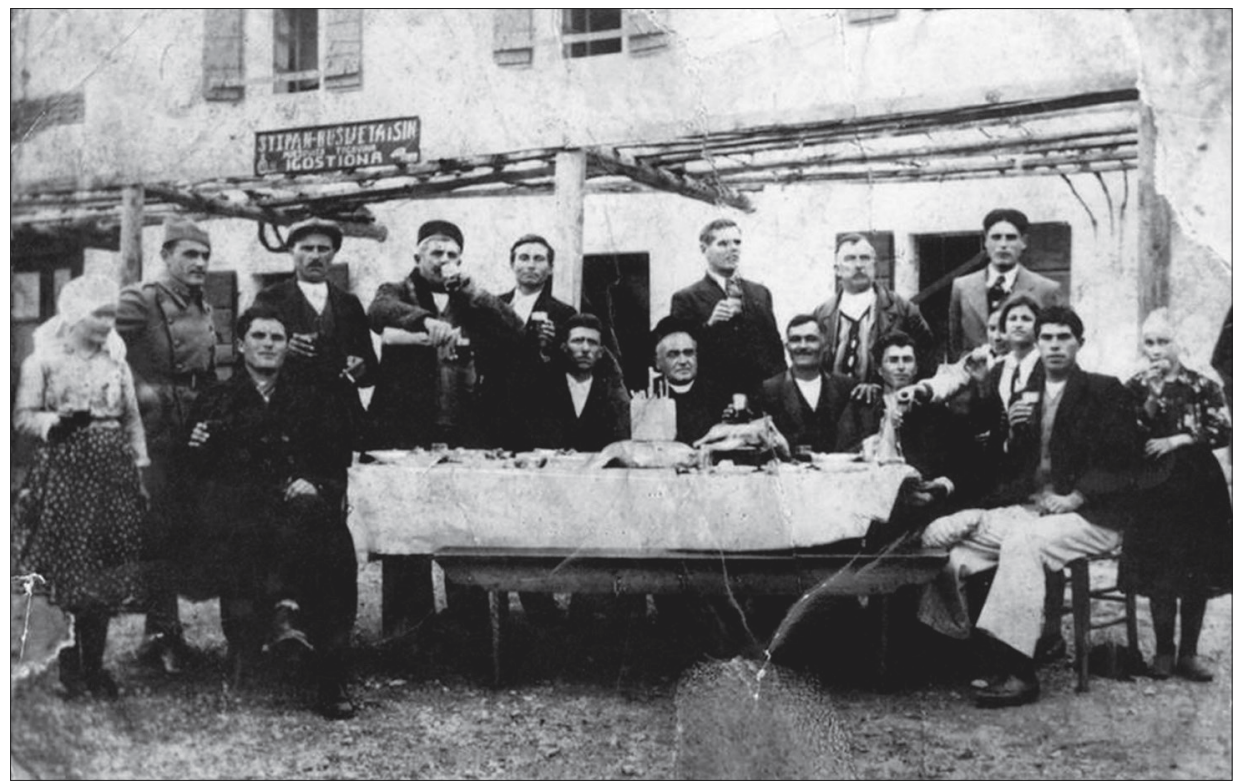

S1. 8. Božićni ručak kod Stipana Bušljete upriličio je don Ante Adžija nakon uspješnog probijanja Bile ceste od 1943. do 1937., snimatelj nepoznat, izvor: https://hr-hr.facebook. $\mathrm{com} /$ Stare slike i razglednice Starigrada-Paklenice i okolice

pakleničkih prirodnih znamenitosti preuzima Podružnica, koja živi $i$ radi za podvelebitske krajeve. ${ }^{25} \mathrm{~S}$ uglednim planinarima, osobito onima iz državne i banske uprave, gostima obitelji Maričić i gostionice Moka raspravljao je već 1929. o turističkom razvoju sela u budućnosti. ${ }^{26}$ Planirao je izgradnju puta od Šsošića preko Aptovca do V. Rujna, ali taj projekt nije stigao realizirati, zbog ratnih previranja. ${ }^{27}$

\section{Vodovod}

Ideju o gradnji vodovoda iz V. Paklenice pokrenu je u Podružnici već 1932. pa je 1935. molio bansku i državnu upravu za dodjelu sredstava za gradnju vodovoda V. Paklenica - Starigrad. Sredstva su odobrena i gradnja

${ }^{24}$ Đ. PANY, 1937, 116-118.

${ }^{25}$ Isti izvor kao bilješka 18.

${ }^{26}$ Đ. RUŽIĆ, 1929, 149-152.

${ }^{27}$ Kazivač: Jerolim Role Petričević, r. 1924., Starigrad-Paklenica; Iz zapisnika od 22. 3. 1936, Arhiv muzeja Samobor. 


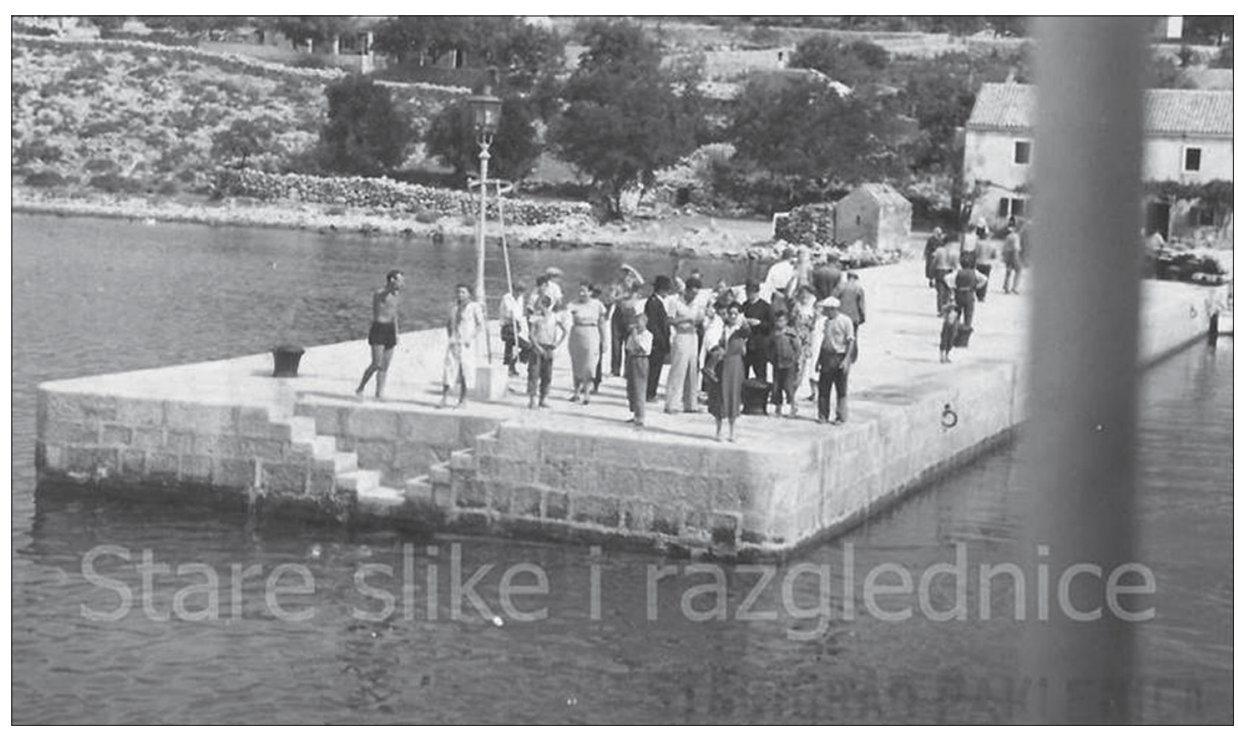

S1. 9. Doček/ispraćaj planinara i turista na rivi, godina i snimatelj nepoznati, izvor: https://hr-hr.facebook.com/Stare slike i razglednice Starigrada-Paklenice i okolice

je započela iste godine u etapama. Do kraja 1936. izgrađena je prva dionica na Kvartiru od vrila Vratrovca, Brezimenjače i Jukića vrila do Donjeg mlina Ramića (Strmac). Druga dionica 1941. do Anić luke. Treća dionica 1942. do naselja Marasovići na ulazu u V. Paklenicu, s uređenom javnom špinom/ slavinom u središtu naselja. Četvrta dionica 1945. do Vasine ogrede u selu i peta završna nakon Drugog svjetskog rata do puntarskog mosta u sela s uređenom javnom špinom/slavinom iznad mosta. Prethodno je bio uređen put od Klanaca do Kvartira za lakše postavljanje vodovoda. Veliku podršku don Anti Adžiji za izgradnju vodovoda pružio je prijatelj Umberto Girometta 1935., pa je radi toga sa stručnim timom prethodno obavio pripremna istraživanja za kaptiranje izvora u V. Paklenici. ${ }^{28}$

\section{Turizam}

Don Ante Adžija isticao je važnost dviju Paklenica u planinarskoturističkom razvoju sela, pa Podružnica nastoji da podigne moralno i materijalno cijelu župu, od čega će imati koristi svi žitelji. Vizionarski je

${ }^{28}$ Vidi članak u listu Novo doba, br. 193, Split, 19. 8. 1935. 


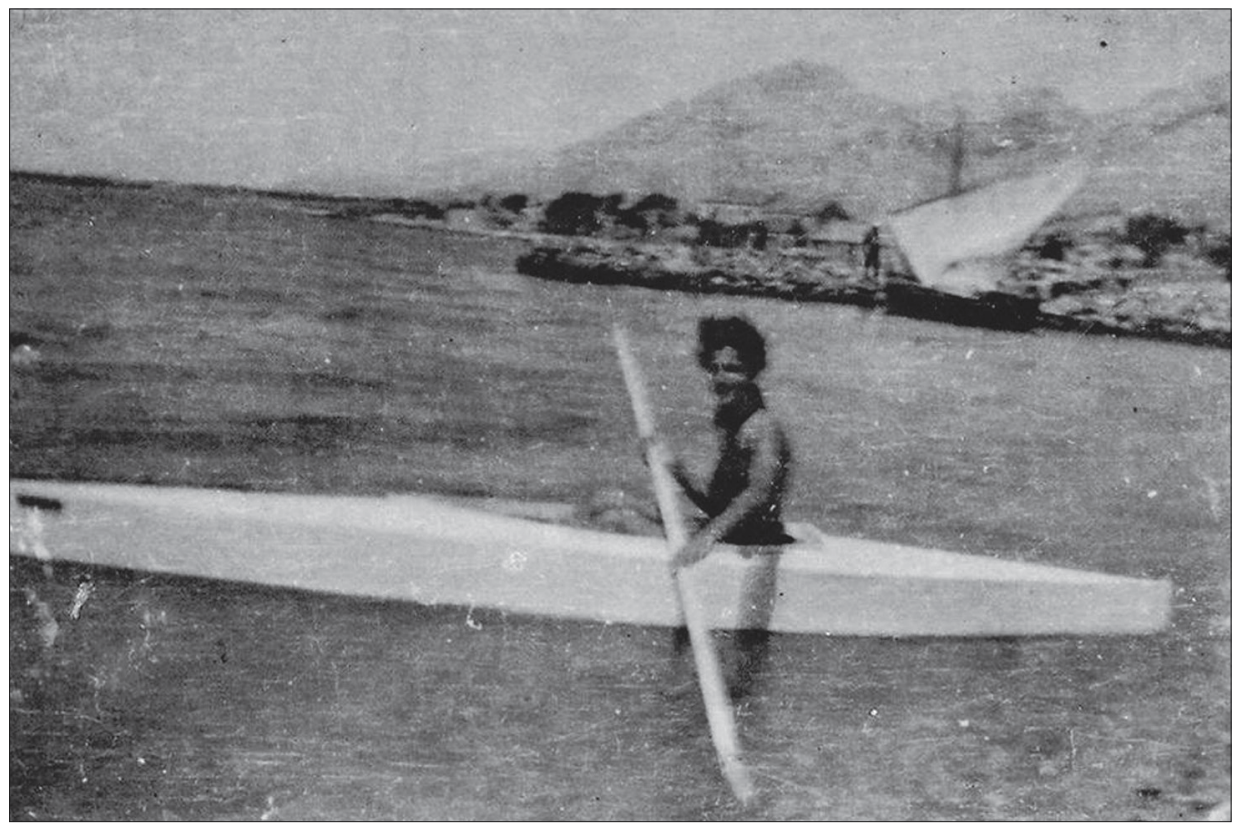

Sl. 10. Turizam u Starigradu-Paklenici između dva svjetska rata, godina i snimatelj nepoznati, izvor: https://hr-hr.facebook.com/Stare slike i razglednice StarigradaPaklenice i okolice

spoznao da se njegova budućnost temelji na spoju planinskog i morskog turizma (S1. 9, 10). Za taj spoj planirao je izgradnju već spomenutog "Morskog planinarskog doma" na Večkom polju. Kada se završe sve prometnice turizam će postati glavna gospodarska grana u budućem razvoju sela. Svako ljeto dolaze planinari iz Austrije, Njemačke i drugih stranih zemalja da se dive Velebitu. ${ }^{29}$ Svim raspoloživim sredstvima radi na promicanju turizma, jer je on jedini spas Podgorcima. ${ }^{30}$ Zato Podružnica pokreće sve mogućnosti da svijet upozna naše prirodne ljepote pa se 1936. zauzeo u Direkciji pomorskog prometa u Splitu da u parobrodne vozne redove selo Starigrad pod Velebitom, radi promidžbe Paklenice, bude preimenovano u Starigrad-Paklenicu (istaknula autorica). ${ }^{31}$ Tako planinari koji su se javljali u "Hrvatskom planinaru" koriste u svojim člancima novi naziv sela. ${ }^{32}$ Također se iz priloženog ovjerenog dokumenta iz

\footnotetext{
${ }^{29}$ Iz zapisnika od 1. 4. 1934, Arhiv muzeja, Samobor.

${ }^{30}$ Isti zapisnik.

${ }^{31}$ Iz zapisnika od 22. 3. 1936, Arhiv muzeja, Samobor.

${ }^{32}$ A. VOKIĆ, 1940, 207-210.
} 


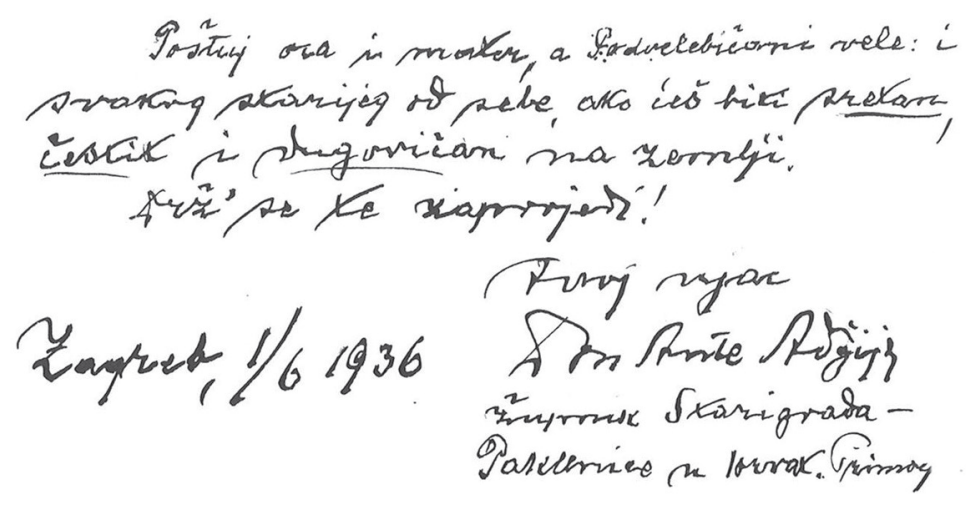

S1. 11. Moralno-etička poruka don Ante Adžije nećakinji dr. Darinki Čop iz koje je razvidno da je on župnik sela s novim imenom: Starigrad-Paklenica u Hrvatskom Primorju (privatni arhiv pok. dr. Darinke Čop)

1941., vidi da don Adžija piše ime sela novim imenom. Isto čini i u privatnoj obiteljskoj dokumentaciji (Sl. 11, 12). Poslije Drugog svjetskog rata, kada je Paklenica 1949. službeno proglašena Nacionalnim parkom, dvočlani naziv uspješno je povezao planinski i morski turizam. Nema sumnje da su mu u ovakvim aktivnostima u razvoju turizma bili uzor i podrška domaći i strani uvaženi gosti i planinari, koji su već početkom 20. st. u listu "Hrvatski planinar" opisivali i propagirali prirodne ljepote južnog Velebita. Budući da je istovremeno pokretao nekoliko projekata, čelni ljudi banske i državne uprave dolazili su u vizitaciju da se uvjere u važnost i značaj svakog projekta i nakon toga odobravali sredstva za završetak radova. Jedan od ključnih bio je ministar Banske uprave u Spitu Marko Kožul, koji je 1936. obišao plažu od Šumarije do Kuline Večke i Selina. Uvjerio se da nijedno mjesto na gornjem Jadranu nema tako duge i podesne obale za kupališta i plaže, pa je obećao daljnju pomoć za procvat južnopodgorskoga kraja. ${ }^{33}$

\footnotetext{
${ }^{33}$ Iz zapisnika od 28. 4. 1936, Arhiv muzeja, Samobor.
} 


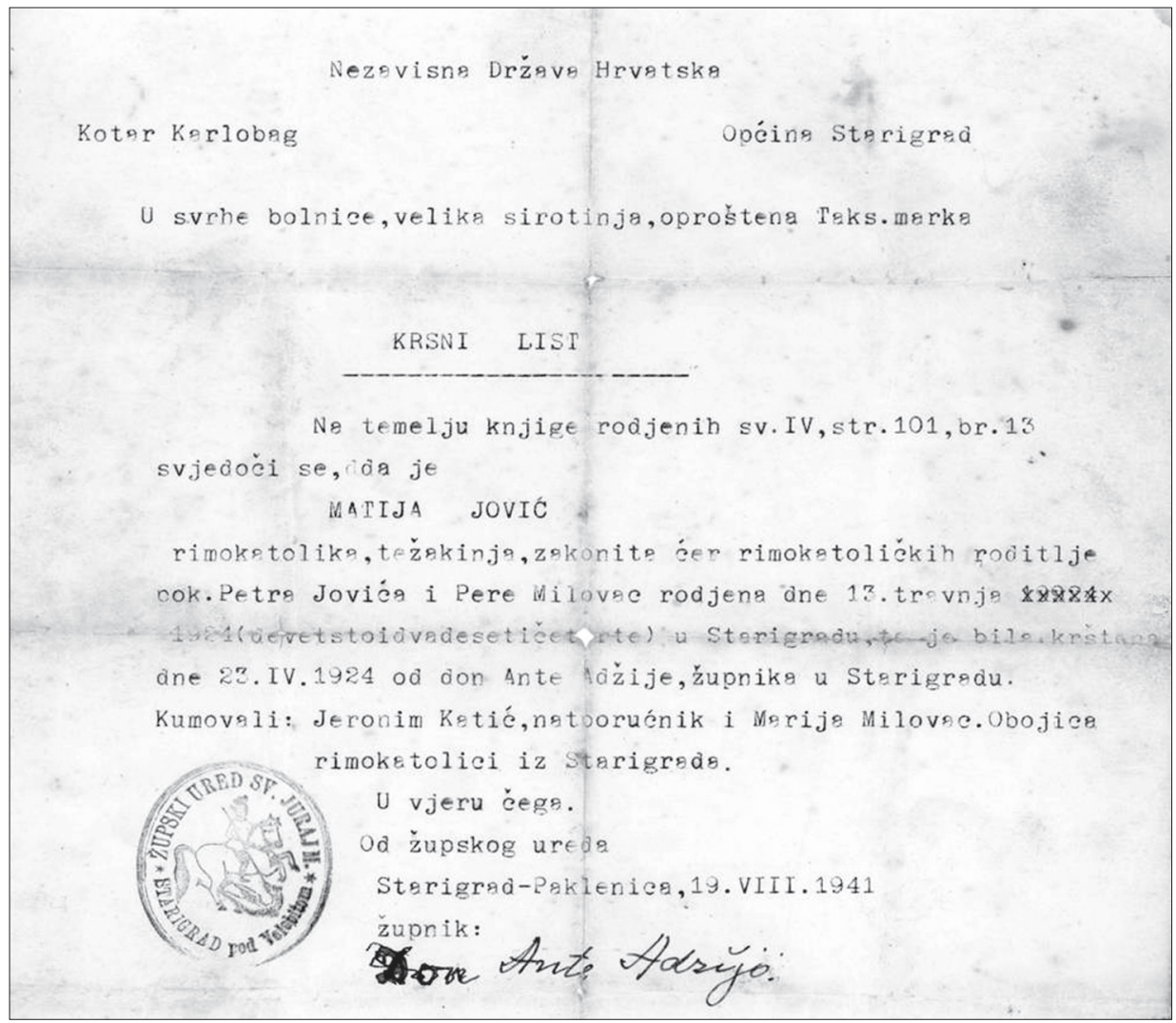

Sl. 12. Krsni list iz 1941, potvrđuje da je u NDH Starigrad općina i da se službeno zove Starigrad-Paklenica i da pripada kotaru Karlobag (privatni arhiv M. Trošelj)

\section{Prosvjetiteljstvo i zdravstvo}

Podružnica se naročito istakla u kulturnom i prosvjetnom radu među žiteljima. Prema prijedlogu don Ante Adžije, Umberto Girometti održavao je 1935. predavanja o gajenju i podizanju šuma, o čuvanju ljekovitih biljaka kao i drugih prirodnih znamenitosti Velebita, o potrebi izgradnje vodovoda, ekologiji i turizmu. ${ }^{34}$ Članovi podružnice održavali su poučna predavanja iz prirodnih znanosti, gospodarstva i zdravstva: o higijeni u stanovima, odijevanju i prehrani. Propagirali su, prema prosvjetiteljskim aktivnostima Škole narodnog zdravlja "Andrija Štampar,"što veću čistoću po kućama i oko kuća pa je liječnik

${ }^{34}$ Iz zapisnika od 13. 2. 1936, Arhiv muzeja, Samobor. 
Romano Jelić na tu temu 1939. održao tri predavanja žiteljima u selu i na Rujnu. Učitelj Mihovil Maričić govorio je o važnosti prosvjetnog i kulturnog rada u ekonomskom napretku sela. Članovi Podružnice tražili su da se ljeti na Rujnu održavaju tečajevi u planinarskom skloništu (izgrađeno kraj crkve 1937.) za domaćice o mljekarstvu, sirarstvu i narodnom vezivu, a za muškarce o pčelarstvu i voćarstvu. ${ }^{35}$ Don Ante Adžija nastojao je da se u selu osnuje "Hrvatski Radiša" pa bi se obučilo nekoliko mladića u pčelarstvu, voćarstvu i poljodjelstvu. Ukazivao je da se što više sade smokve, jer trgovanjem u Lici za njih u zamjenu dobiju drugu važnu hranu. Isto tako vidio je ekonomski prosperitet u sadnji maslina $\mathrm{i}$ bajama pa bi svi ti proizvodi donosili dobru zaradu. ${ }^{36}$

Zadatak Podružnice je promicanje dobrobiti podvelebitskih sela $\mathrm{u}$ poboljšanju gospodarstva pa don Ante Adžija uspoređuje stanje u 1936. s onim od prije deset godina (1926.) i naglašava da za selo u banovinskim i državnim vlastima nitko nije znao, a danas su sve vladine i nevladine institucije pokrenute da propagiraju i rade na upoznavanju naših prirodnih ljepota i krajeva. U nadzornom odboru Podružnice su dr. Romano Jelić, liječnik iz Novigrada, koji je na zamolbu don Ante Adžije povremeno dolazio ordinirati u Starigrad-Paklenicu, Grga Oštrić konzervator, također prijatelj iz Novigrada, kapetan Tomislav Glavan i Mijat Parić. ${ }^{37}$ Godine 1937./38. držao je presudnim za dovršenje većine važnih projekata: putovi kroz Paklenicu, staza u Manitoj peći, cesta ObrovacTribanj-Mandalina, vodovod (nije stigao do sela za njegova života), planinarsko sklonište na V. Rujnu, važno za planinare $\mathrm{i}$, kako je već rečeno, za održavanje predavanja i tečajeva za unapređivanje gospodarstva i zdravstvenih prilika na južnom Velebitu.

\section{Rad na prikupljanju, čuvanju i spašavanju kulturno - povijesne baštine}

Uz duhovni i materijalni rad u svekolikom razvoju sela, don Adžija je paralelno proučavao kulturno-povijesnu, napose sakralnu baštinu u Podgorju i u planini. Bio je njezin čuvar i promotor. Kao povjerenik Kninskog muzejskog društva i član Hrvatskog starinarskog društva u Kninu u tome je imao svoje uzore drugih župnika u Dalmaciji, kao što su fra Lujo Maruna, don Mate Klarić, prijatelj Stjepan Gunjača i drugi s kojima se susretao za vrijeme franjevačkog redovništva. Posvetio se već prvih godina svoga pastoralnog rada

\footnotetext{
${ }^{35}$ Iz zapisnika od 22. 3. 1936, Arhiv muzeja, Samobor.

${ }^{36}$ Iz zapisnika od 19. 2. 1939, Arhiv muzeja, Samobor.

${ }^{37}$ Iz zapisnika od 20. 3. 1937, Arhiv muzeja Samobor.
} 


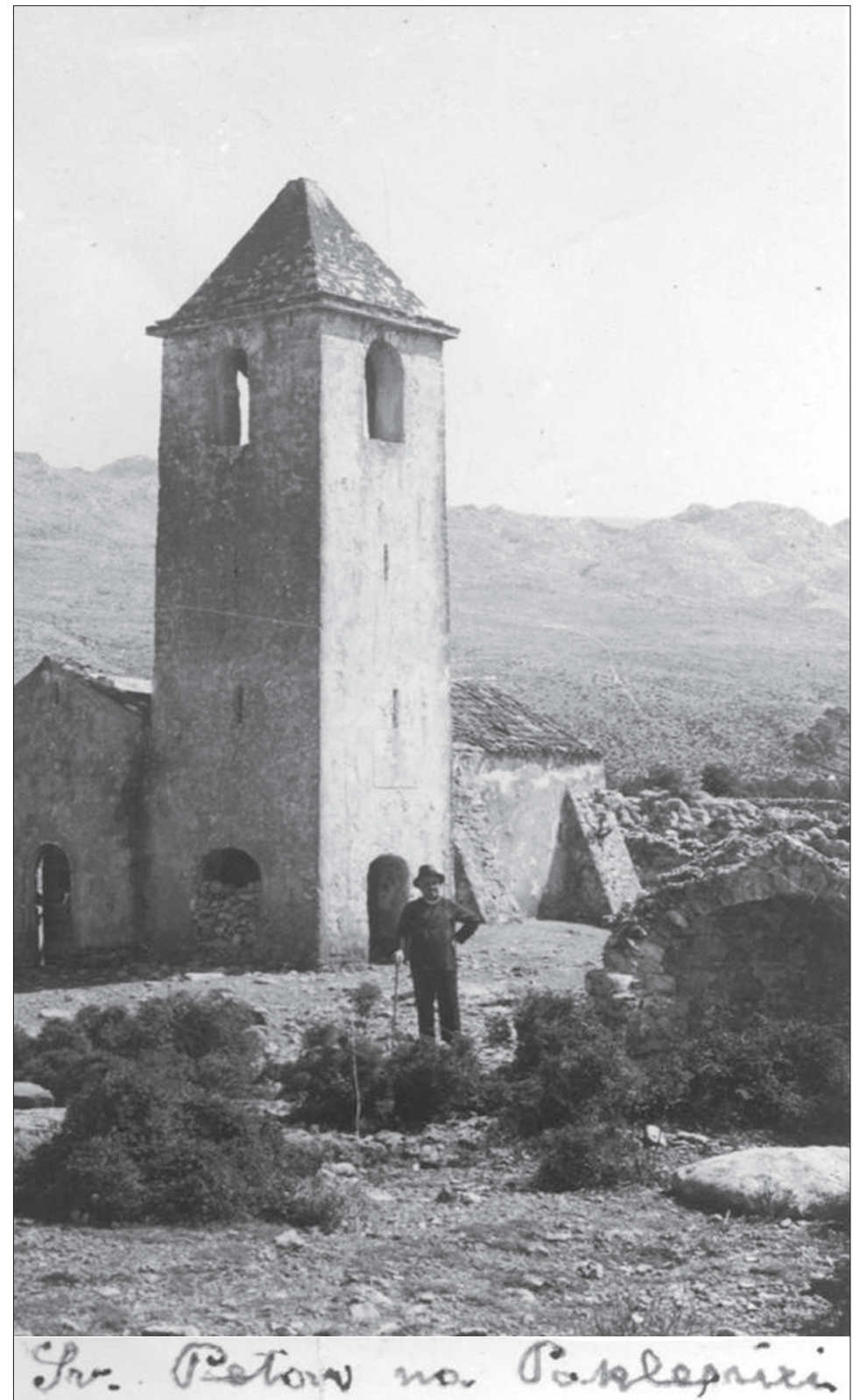

Sl. 13. Don Ante Adžija ispred crkve sv. Petra prije istraživanja i restauracije 1939.1940., snimatelj i jedan od restaurator ing. Mirko Čop (Ostavština rođaka Božidara Adžije, Arhiv Konzervatorskog odjela Ministarstva kulture, Zadar) 

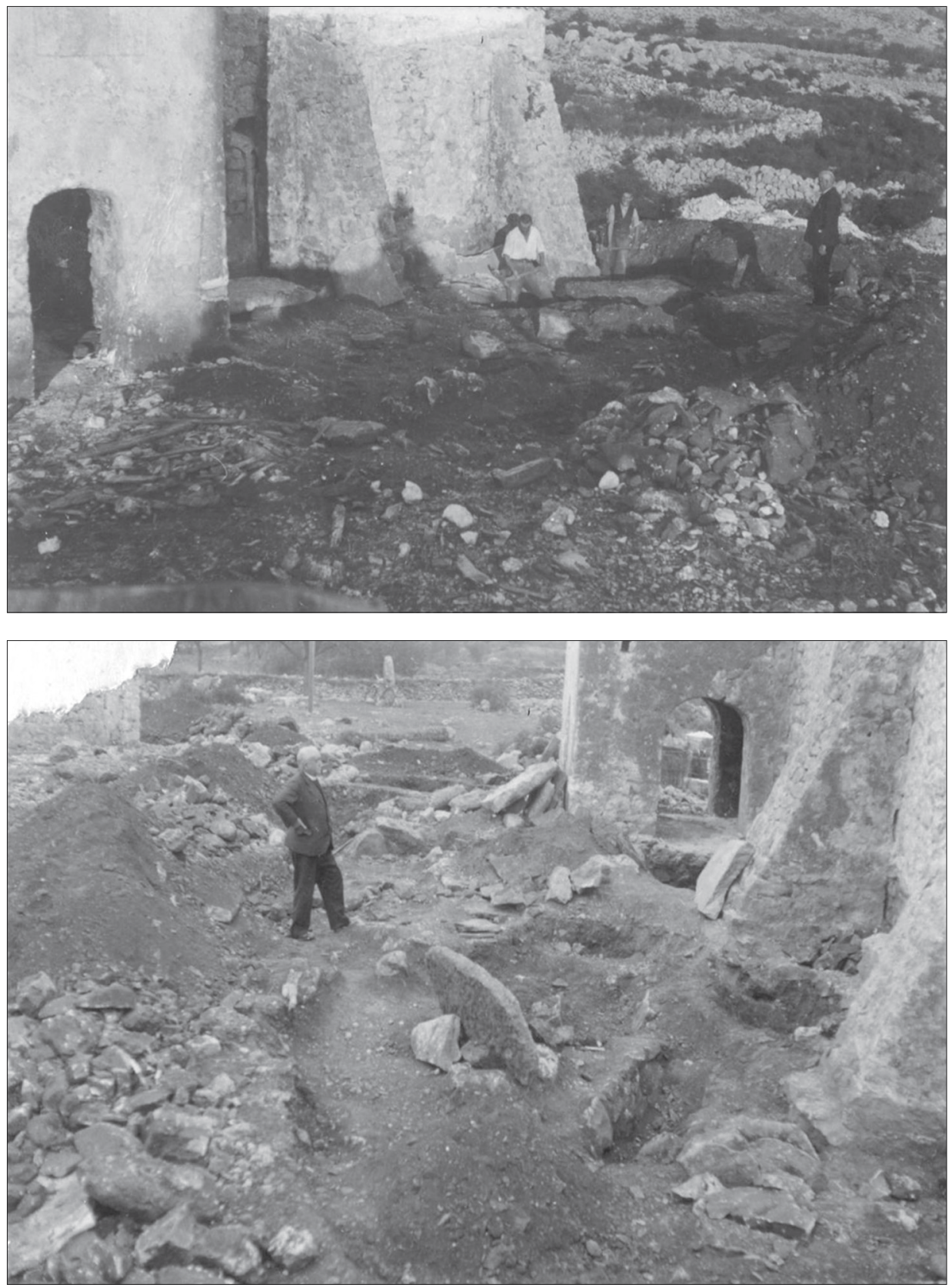

Sl. 13a i 13b. Tijek istraživačkih radova i restauracije, isti izvor 
u selu prikupljanju arheološke spomeničke građe antičkog Argyruntuma (nikada znanstveno istraženoga) i starohrvatske srednjovjekovne sakralne baštine (ruševina srednjovjekovne kasnogotičke grobljanske crkve sv. Jure (nikada znanstveno istražene) $i$ crkve sv. Petra (istraživane i restaurirane $u$ više navrata tijekom 20. st.). Na kraju nedjeljnih misa ili za vrijeme vjeronauka, upućivao je apel Puntarima, ako naiđu na neko neobično kamenje, mozaike, opeku, keramiku, metalne predmete i druge vrste ulomka na Punti (Argyruntum) da mu donesu u župnu kuću. ${ }^{38}$ Župljani su se odazvali tom apelu, osobito djeca. Namjera mu je bila utemeljiti Zavičajni muzej i na taj način sačuvati kulturno-povijesnu baštinu Starigrada-Paklenice. Cila jedna zapadna kamara u Popovoj kući bilaj' puna kamenja i još gaj' bilo pod škalinan. ${ }^{39}$ Prvi svjedok zbirke vjerojatno oko 1926. bio je Branimir Gušić. Moguće je da su se upoznali i sprijateljili već dolaskom don Ante Adžije 1923., jer je te iste godine Gušić bio gost u gostionici Moka za vrijeme svojih velebitskih istraživanja. O viđenoj građi u muzejskoj zbirci, Gušić je pisao u dva navrata, 1969. i 1973. Ovdje treba spomenuti da je do 1944. u Starigradu-Paklenici župnik bio slavni don Ante Adžija u čijoj se župnoj kući nalazio pravi mali zavičajni muzej. Uzbirci je bilo ulomaka pleterne ornamentike koje je don Adžija pronašao oko crkve sv. Petra i grobljanske crkve sv. Jure. ${ }^{40}$ Vodio je evidenciju o svakom pronađenom nalazu. Veliki dio građe nestao je u Drugom svjetskom ratu kada je kuća spaljena, a preostali dio su oko 1950. odvezli kamionon niki ljudi u nepoznaton pravcu. To smo gledali stric i ja Kraj Murve kad smo pitural kaic. ${ }^{41}$ Posebno se posvetio crkvi sv. Petra zbog pronađenih starohrvatskih pleternih ulomaka tijekom svoga pastoralnog rada, pa je 1939. vršio pripreme za njezinu obnovu i uređenje. Nakon prikupljenih sredstava od državnih i privatnih donatora restauracija je izvršena 1940. (Sl. 13, 13a, 13b, 14, 15). ${ }^{42}$ Premda posljednja arheološka istraživanja i restauracija crkve sv. Petra nisu dokazala postojanje pleternih ulomaka iz predromaničkog razdoblje, ${ }^{43}$ autorica ovoga rada smatra da ih je bilo u don Adžijinom Zavičajnom muzeju, međutim poznato je da je kompletna građa nestala tijekom i poslije Drugog svjetskog rata. Nažalost ni prilikom obnavljanja kuće 1970. nije se ništa pronašlo u ruševinama. Provodio je istraživanja i na V. Rujnu vjerujući u mogućnost

\footnotetext{
${ }^{38}$ Kazivanja K. Trošelj (1923-2009.) i I. Trošelj (1921-2012.), 1985.

${ }^{39}$ Isti kazivači.

${ }^{40}$ B. GUŠIĆ, 1973,39; A. GLAVIČIĆ, 2003, 38, 40-41, 62,71-72, prema Gušiću.

${ }^{41}$ Kazivanja K. Trošelj, 1985.

${ }^{42}$ O tom radu izvijestile su zagrebačke Novosti 1940. ,XXXIV, br.4, str. 11; A. RUKAVINA,

${ }^{43}$ R. JURIĆ, 2003, 649-658; 2013, 648-649.
} 1989, 91-92. 


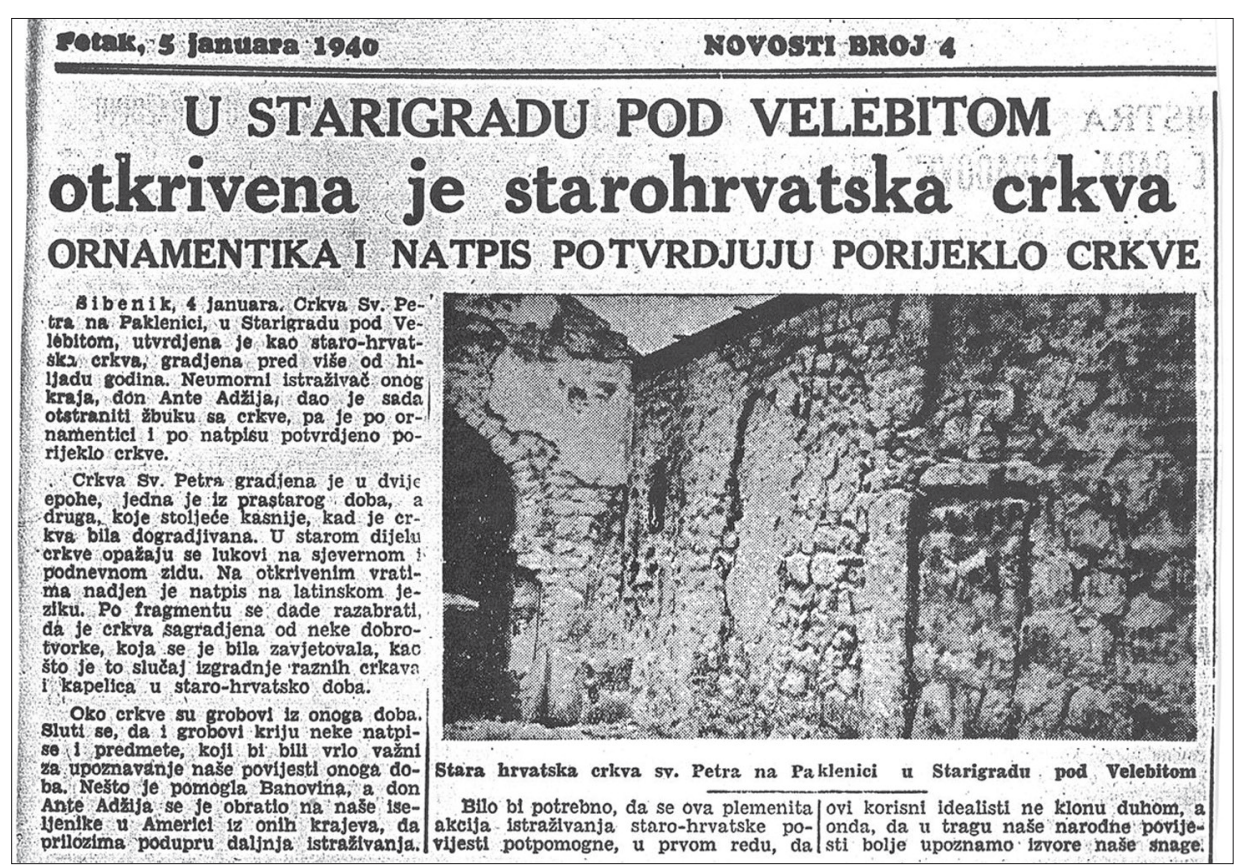

S1. 14. Novinska vijest o restauraciji crkve sv. Petra nepoznatog autora u Šibeniku, 1940.

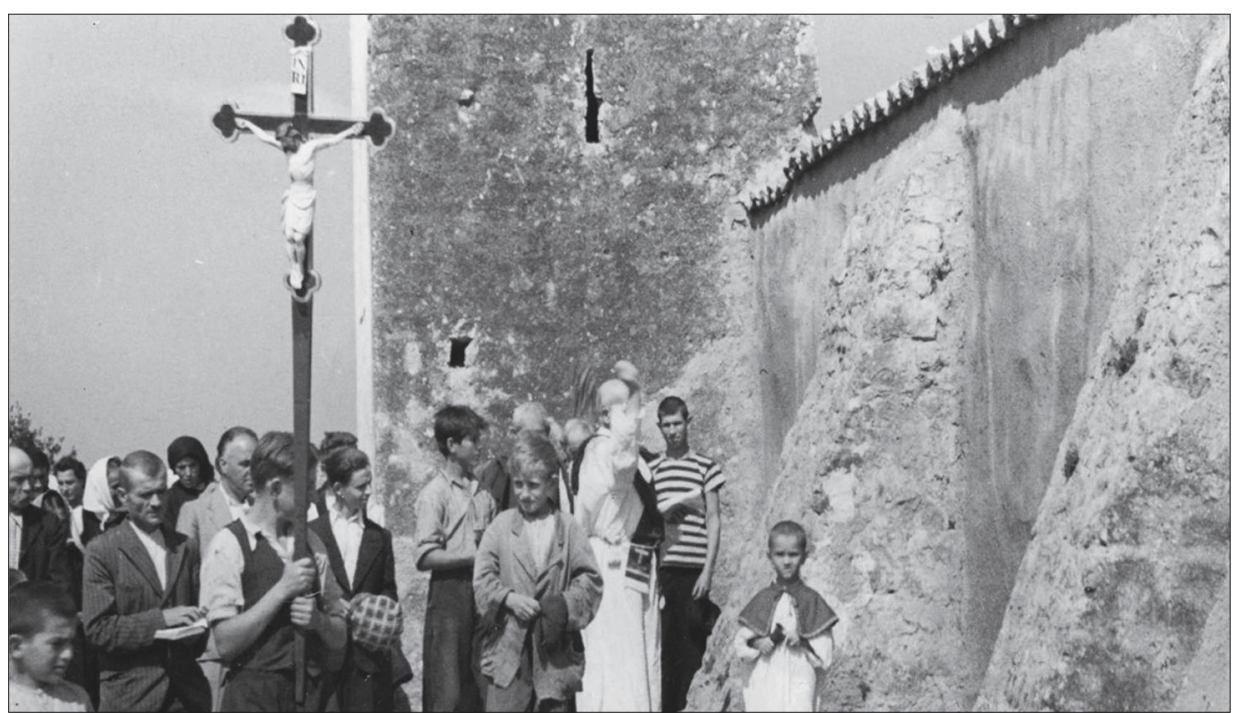

Sl. 15. Posveta crkve sv. Petra nakon restauracije 1940., snimatelj Mirko Čop, izvor: https:/hr-hr.facebook.com/Stare slike i razglednice Starigrada-Paklenice i okolice 
nalaza iz antičkog doba. Na dan Velike Gospe 1980. na V. Rujnu, Ante Glavičić donosi zapis izjave Đorđa Pekote iz Zadra (rođen u Novigradu) koji se sjećao i bio svjedokom da je don Ante Adžija nalazio ostatke antičkih villa rustica na V. Rujnu. ${ }^{44}$ Godine 1941. sudjeluje u spašavanju starohrvatske spomeničke građe iz Ravnih kotara (Pridraga). Iste godine Stjepan Gunjača vršio je iskapanja na položaju Mijovilovac u Pridrazi (Ravni kotari). Spomeničku građu smjestio je u Novigradu kod Grge Oštrića, a odatle ju je trebalo prebaciti u Kninski muzej. Iz anketiranog Novigrada to se nije moglo izvesti legalno pa su se obojica dogovorili s don Antom Adžijom da se građa prebaci ilegalno, noću brodom u Starigrad-Paklenicu u župnu kuću. Akcija je izvedena uspješno pa je Gunjača 19. 6. 1941. pošao iz Knina preko Gračaca i Karlobaga u Starigrad-Paklenicu da preuzme pridrašku arheološku građu i prenese je u Knin istim putem kojim je i došao. Nezaboravan mi je ostao lik don Ante Adžije; bio je sav sretan što je nečim mogao pridonijeti svom patriotskom stavu. ${ }^{45}$ Nakon uspješnog pothvata don Ante Adžija uputio je pismo Gunjači u kojem mu javlja da ga je spasio od smrti 1941., one večeri kada su sjedili i razgovarali pred župnom kućom i osluškivali zloslutni brod na moru koji se približavao Bikariji. ${ }^{46}$

\section{Umjesto zaključka (1941-1944.)}

U ratnom se razdoblju don Ante Adžija osobito posvetio humanitarnom i pastoralnom radu. Njegovo sveto uvjerenje bilo je: Činimo ono što je Krist činio, a neznalica će uvijek biti. Molitvom uklonimo štetočine za dobrobit čovjeka. ${ }^{47}$ Velikan Starigrada-Paklenice došao je u župu da unese duhovni i civilizacijski polet, izvuče je iz anonimnosti, uzdigne na hrvatske i europske razine i osvijetli joj je put za bolju budućnost. Njegove su zasluge nebrojene. Stalno se zalagao za rješavanje važnih gospodarskih, socijalnih, zdravstvenih, prometnih, prosvjetnih, kulturnih, vjerskih i drugih pitanja i problema u razvoju Starigrada-Paklenice. Bio je nadaleko poznat po svojoj društvenosti, dobročinstvu i humanosti. Istinski čovjekoljubac i domoljub, osuđivao je sve vrste nasilja i agresije bez obzira od kojeg napadača potjecali. Zato je žrtvovan poput Krista. Smrt je prvi put izbjegao1941., nakon obavljene restauracije crkve sv. Petra i u tijeku spašavanja pridraške građe. ${ }^{48}$ Nažalost 1944. nije ju mogao izbjeći, jer su napadači udruženi došli i s morske i s

\footnotetext{
${ }^{44}$ A. GLAVIČIĆ, 1981-1982, 102, bilješka 17; 2003, 38, S1. 5,6.

${ }^{45}$ S. GUNJAČA, 1961, 809; 1975, 674.

${ }^{46}$ S. GUNJAČA, 1961, 809; 1975, 674.

${ }^{47}$ Kazivanja Darinke Čop (1924-2013.), nećakinje don Ante Adžije, 2008.

${ }^{48}$ S. GUNJAČA, 1963, 29, S1. 4
} 

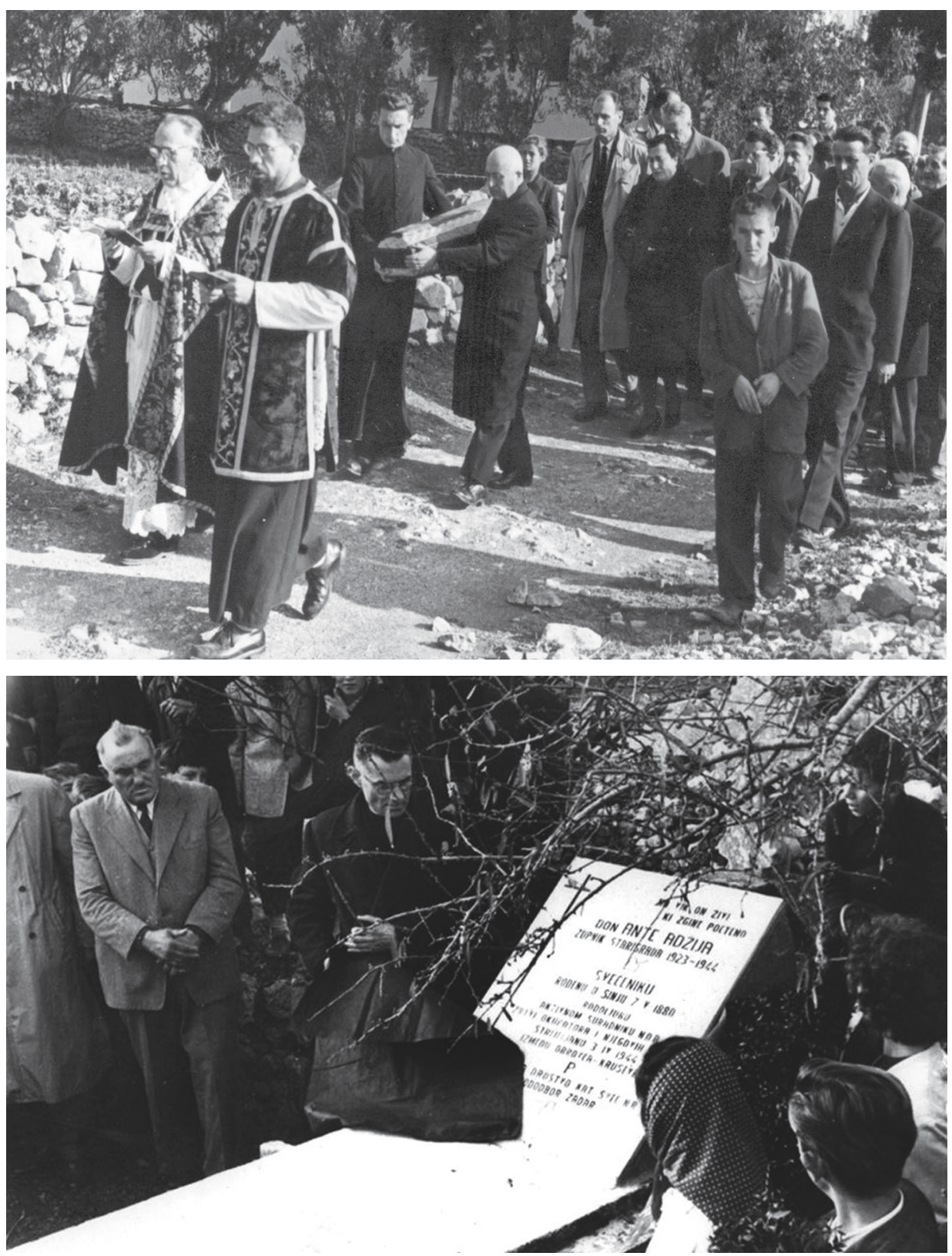

S1. 16. i 16a. Eshumirani ostaci don Ante Adžije iz Kruševačke okolice, preneseni su u starigradsko groblje na Punti 1959. (privatni arhiv pok dr. Darinke Cop). Grob s nadgrobnom pločom devastiran je oko 2000. 
kopnene strane. ${ }^{49} \mathrm{~S}$ mjesta pogibije u okolici Kruševa, preneseni su 1959. njegovi zemni ostaci u obiteljski grob na starom puntarskom groblju u Starigradu-Paklenici (S1. 16, 16a). ${ }^{50}$ Danas ga više nema, devastiran je na početku 21. st.

Ista sudbina zadesila je i njegov dokumentacijski arhiv 1944., spaljen u župnoj kući, a iz župne crkve sv. Jure i kuće M. M. Smokrovića sve su crkvene knjige, razni spisi i Matice bačeni u more. ${ }^{51}$ Danas smo kulturno-povijesni i društveno-moralni siromasi: zaboravili smo velikana i njegovo djelo.

\section{Literatura i izvori}

Umberto GIROMETTA, Velikom Paklenicom na Vaganski vrh: Starigrad, Hrvatski planinar, br. 4, Zagreb, 1933, 106-113.

Ante GLAVIČIĆ, Prilog istraživanju starohrvatske sakralne arhitekture na primorskim padinama Velebita i Velike Kapele (I.dio), Senjski zbornik, IX, Senj, 1981-1982, 91-114.

Ante GLAVIČIĆ, Pregled starokršćanske i srednjovjekovne baštine Like, Podgorja i grada Senja, Senjski zbornik, 30, Senj, 2003, 21-82.

Stjepan GUNJAČA, Sjećanje uz brigu oko spašavanja naših spomenika u Nob-u, Mogućnosti, 8, Split, 1961, 806-684.

Stjepan GUNJAČA, Srednjovjekovni Dolac kod Novigrada, Starohrvatska prosvjeta, vol. III, No. 8-9, Split, 1963, 7-66.

Branimir GUŠIĆ, Naseljenje Like do Turaka, Lika u prošlosti i sadašnjosti 2, Karlovac, 1973, 13-60.

Radomir JURIĆ, Crkva sv. Petra u Starigradu-Paklenici, Senjski zbornik, 30, Senj, 2003, 649-658.

Radomir JURIĆ, Arheološka istraživanja crkve sv. Petra i njezina okoliša u StarigraduPaklenici, Senjski zbornik, 40, Senj, 2013, 647-656.

I. JURIČIĆ, Sa Velebita, Planinarski vjesnik, 2, 1912, 61.

Ivan KRAJAČ, Novogradnje putova na Velebitu i značenje njihovo: 5. Novi obalni put na južnom Velebitu, Hrvatski planinar, br. 10, Zagreb, 1930, 311-316.

Đuro PANY, Morem i kopnom od Sušaka do Ulcinja, Hrvatski planinar, br. 4, Zagreb, 1937, 116-118.

Željko POLJAK i suradnici, Velebit, Zagreb, 1969.

Ante RUKAVINA, Zvona ispod zvijezda: Putopisna i povijesna razmatranja o velebitskim sakralnim građevinama, "Ličke župe," Gospić, 1989.

\footnotetext{
${ }^{49}$ Autorica posjeduje pisana i usmena svjedočanstva samo njoj poznatih svjedoka o ubojstvu don Ante Adžije, a ona su suprotna od onoga što je u dosadašnjoj literaturi zapisano o njegovoj smrti. Građa je arhivirana i bit će objavljena u budućoj monografiji.

${ }^{50}$ Vidi članak u Narodnom listu, Zadar, 5. 12. 1959.

${ }^{51}$ Kazivanja: I. Trošelj (1921-2012.) i G. Smokrović (1925-2000.).
} 
Đuro RUŽIĆ, Manita peć, Hrvatski planinar, br. 6, Zagreb, 1929, 149-152.

Rozario ŠUTRIN, Dvanaestorici naše umorene braće, Nadbiskupski ordinarijat, Zadar, 1995.

Rozario ŠUTRIN, Žrtve bogoljublja i čovjekoljublja, Zadar, 2002.

Mirjana TROŠELJ, Don Ante Adžija: uz 60. obljetnicu smrti, Zadarska smotra, 1-3, 2003, 121-123.

A. VOKIĆ, Karlovac, Od Medka do Obrovca, Hrvatski planinar, 7, Zagreb, 1940, 207-210.

\section{Izvori}

Arhiv muzeja Samobor, Spis 28, Starigrad pod Velebitom, Zapisnici i dopisi Podružnice

"Paklenica" sa Središnjicom u Zagrebu od 1932-1940.

Arhiv HPS, Zagreb, "Hrvatski planinar," od 1923-1940.

Internet stranica: https://hr-hr.facebook.com/Stare slike i razglednice StarigradaPaklenice i okolice

\section{Kratice}

HPS - Hrvatski planinarski savez

HPD - Hrvatsko planinarsko društvo

HP - Hrvatski planinar (časopis) 


\section{DON ANTE ADŽIJA - A FORGOTTEN LEADING FIGURE OF STARIGRAD-PAKLENICA}

\section{Summary}

Presented in the paper is the exceptional biography of the parish priest Don Ante Adžija (1880-1944), the most significant and most distinguished person of the $20^{\text {th }}$ century from StarigradPaklenica, who was unfairly and unjustifiably neglected in the perception of the pastoral, humanitarian, cultural, socio-economic, enlightening and other activities in the parish in the period between the two world wars. Thanks to him, the village from the first half of the $20^{\text {th }}$ century became the second, even to this today, most developed touristic municipality on the stretch from Karlobag to Zadar. The purpose of this paper is to raise awareness about such individuals, great figures, to whom by their work their people and the culture to which they belonged are indebted.

The paper consists of three parts. In the first part is described his life path, ancestry, schooling and priestly activity until moving into the parish of Starigrad-Paklenica in 1923. In the second part is described his work in the new parish on the religious, cultural-historical, enlightening, health, mountaineering-touristic and economic plan, in order that "in the most abandoned region of the Zadar archdiocese ${ }^{\prime \prime}$ he sets the foundations for the overall improvement. On these principles Starigrad-Paklenica developed into a modern touristic municipality. In the historical context of the first Yugoslavia in the complicated socio-political and economic conditions, which were also reflected in the passive areas of Podgorje, Don Ante Adžija did not lose faith in the realisation of his messianic goals. He loved his people, his old Starigrad people and as God's emissary he used every opportunity and possibility to make their life better. To this end, he developed a collaboration with distinguished personalities from the socio-political, economic and cultural circle of the Littoral and Sava Banovinas (from Rijeka to Split and Zagreb), of distinguished scientists, scientist-mountaineers from Croatia and abroad. A special reference in the paper is made to his research of cultural-historical heritage, the collecting of archaeological material (ancient and Old Croatian sacral monuments), the establishment of a museum in the parish house, and the renovation and maintenance of preserved sacral buildings. As a collaborator with the Museum of Croatian Monuments and a member of the Antiquarian Museum Association in Knin, he participated in the rescuing of Old Croatian heritage from the area of northern Dalmatia in 1941. In the third part, instead of a conclusion, described is how not even the circumstances of the Second World War were able to hinder him, although he had a premonition of death in 1941, he selflessly worked for his parish and parishioners and as the Saviour he helped save man, his people and its heritage all the way until his martyr's death in 1944.

This paper is based on the records of the 'Paklenica' Branch Office of the HPD (Croatian Mountaineering Association) under the title of 'Starigrad under Velebit' from the Archive of the Samobor Museum, articles from the magazine 'Croatian Mountaineer' from the Archive of HPS (Croatian Mountaineering Association) Zagreb, from 1923-1940, newspaper articles and family photographic material and material from unknown sources from the pages of Facebook. Also included in the paper are testimonies from the close relatives of Don Ante Adžija, local people at Starigrad Punta, the notes of respected mountaineers and others who knew him. Expert literature so far has not seriously dealt with him, apart from short records about his pastoral work before his arrival at the Starigrad-Paklenica parish and some information, mostly incomplete or inaccurate,

${ }^{1}$ The parish belonged to the Novigrad deanery as an Apostolic administration of the Yugoslav part of the Zadar archdiocese with its seat in Šibenik. Information: Don Oleg PETROVIĆ, MHist, bishopric archive, Šibenik, 2017 
about his death. The Starigrad-Paklenica creative period from 1923-1944, has not been included in the expert literature, apart from a modest note of the author upon the $60^{\text {th }}$ anniversary of his death. ${ }^{2}$ Therefore, this paper should be considered as a starting point for future research, based on any eventual unidentified archive material which is unavailable at the present time. This primarily relates to archive documentation of the ban administration of both Banovinas and state administration.

All of his handwritten material and documentation stored in the parish house and Parish Church of St George was burnt in 1944, and one part of the written sacral material was thrown into the sea, whereby his pastoral and research-creative biography has been damaged, and with that 'biography' so has the history of Starigrad-Paklenica.

Keywords: Don Ante Adžija, Starigrad-Paklenica

${ }^{2} \mathrm{M}$. TROŠELJ, 2003, 121-123. 